\title{
Ubinas: the evolution of the historically most active volcano in southern Peru
}

\author{
Jean-Claude Thouret - Marco Rivera - Gerhard Wörner $\cdot$ Marie-Christine \\ Gerbe · Anthony Finizola $\cdot$ Michel Fornari - Katherine Gonzales
}

\begin{abstract}
Ubinas volcano has had 23 degassing and ashfall episodes since A.D. 1550, making it the historically most active volcano in southern Peru. Based on fieldwork, on interpretation of aerial photographs and satellite images, and on radiometric ages, the eruptive history of Ubinas is divided into two major periods. Ubinas I (Middle Pleistocene $>376 \mathrm{ka}$ ) is characterized by lava flow activity that formed the lower part of the edifice. This edifice collapsed and resulted in a debris-ava-
\end{abstract}

J.-C. Thouret (区)

Laboratoire Magmas et Volcans,

Université Blaise-Pascal et CNRS, OPGC,

5 rue Kessler, 63038 Clermont-Fd Cedex, France

e-mail: thouret @opgc.univ-bpclermont.fr

Fax: 04-73-34-67-44

\section{Rivera}

INGEMMET,

Dirección de Geología Ambiental,

Av. Canada 1470, La Victoria, Lima, Perú

G. Wörner

GZG, Abt. Geochemie,

Universität Göttingen,

Goldschmidtswasse 1, 37077 Göttingen, Germany

\section{M.-C. Gerbe}

Département de Géologie-Pérrologie-Géochimie, Université Jean Monnet et Laboratoire Magmas et Volcans,

Rue Dr. P. Michelon, 42023 Saint Etienne Cedex, France

\section{A. Finizola}

Istituto Nazionale di Geofisica e Vulcanologia (INVG-Palermo), Via Ugo la Malfa 153, 90144 Palermo, Italy

\section{Fornari}

IRD, Géosciences Azur,

Université de Nice-Sophia Antipolis,

Parc Valrose, 06108 Nice Cedex 2, France

K. Gonzales

IGP, Instituto Geofísico del Perú,

Regional Arequipa,

Urb. La Marina B 19, Cayma, Arequipa, Peru lanche deposit distributed as far as $12 \mathrm{~km}$ downstream the Rio Ubinas. Non-welded ignimbrites were erupted subsequently and ponded to a thickness of $150 \mathrm{~m}$ as far as $7 \mathrm{~km}$ south of the summit. These eruptions probably left a small collapse caldera on the summit of Ubinas I. A 100$\mathrm{m}$-thick sequence of ash-and-pumice flow deposits followed, filling paleo-valleys $6 \mathrm{~km}$ from the summit. Ubinas II, $376 \mathrm{ky}$ to present comprises several stages. The summit cone was built by andesite and dacite flows between 376 and $142 \mathrm{ky}$. A series of domes grew on the southern flank and the largest one was dated at $250 \mathrm{ky}$; block-and-ash flow deposits from these domes filled the upper Rio Ubinas valley $10 \mathrm{~km}$ to the south. The summit caldera was formed between 25 and $9.7 \mathrm{ky}$. Ash-flow deposits and two Plinian deposits reflect explosive eruptions of more differentiated magmas. A debris-avalanche deposit (about $1.2 \mathrm{~km}^{3}$ ) formed hummocks at the base of the 1,000-m-high, fractured and unstable south flank before $3.6 \mathrm{ka}$. Countless explosive events took place inside the summit caldera during the last $9.7 \mathrm{ky}$. The last Plinian eruption, dated A.D.1000-1160, produced an andesitic pumice-fall deposit, which achieved a thickness of $25 \mathrm{~cm}$ $40 \mathrm{~km}$ SE of the summit. Minor eruptions since then show phreatomagmatic characteristics and a wide range in composition (mafic to rhyolitic): the events reported since A.D. 1550 include many degassing episodes, four moderate (VEI 2-3) eruptions, and one VEI 3 eruption in A.D. 1667.

Ubinas erupted high- $\mathrm{K}$, calc-alkaline magmas $\left(\mathrm{SiO}_{2}=56\right.$ to $71 \%$ ). Magmatic processes include fractional crystallization and mixing of deeply derived mafic andesites in a shallow magma chamber. Parent magmas have been relatively homogeneous through time but reflect variable conditions of deep-crustal assimilation, as shown in the large variations in $\mathrm{Sr} / \mathrm{Y}$ and LREE/HREE. Depleted HREE and $Y$ values in some lavas, mostly late mafic rocks, suggest contamination of magmas near the base of the $>60-\mathrm{km}$-thick continental crust. The most recently erupted products (mostly scoria) show a wide range in composition and a trend towards more mafic magmas. 


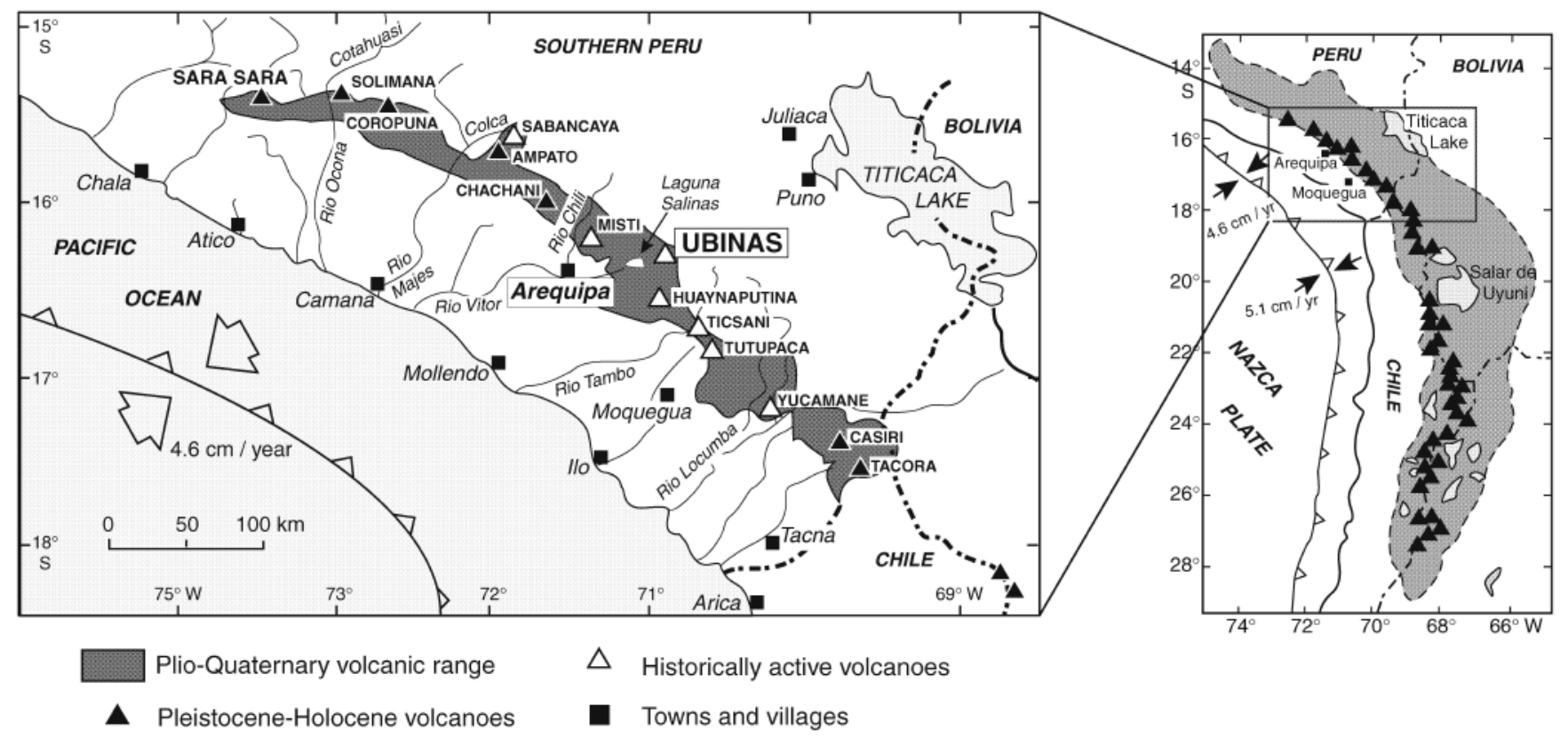

Fig. 1 Geologic setting of the present volcanic range in southern Peru, with emphasis on Ubinas volcano. Inset: Central Andean Volcanic Zone with study area (in box)

Recent eruptions indicate that Ubinas poses a severe threat to at least 5,000 people living in the valley of the Rio Ubinas, and within a $15-\mathrm{km}$ radius of the summit. The threat includes thick tephra falls, phreatomagmatic ejecta, failure of the unstable south flank with subsequent debris avalanches, rain-triggered lahars, and pyroclastic flows. Should Plinian eruptions of the size of the Holocene events recur at Ubinas, tephra fall would affect about one million people living in the Arequipa area $60 \mathrm{~km}$ west of the summit.

Keywords Andes · Ubinas · Eruption history · Radiometric dating · Geochemistry · Fractional crystallization $\cdot$ Mafic magma $\cdot$ Hazards

\section{Introduction}

The Ubinas volcano $\left(16^{\circ} 22^{\prime} \mathrm{S}, 70^{\circ} 54^{\prime} \mathrm{W} ; 5,672 \mathrm{~m}\right.$ a.s.1., Fig. 1) is located in the Quaternary volcanic range in southern Peru, which belongs to the Central Volcanic Zone (CVZ) of the Andes. Ubinas is $230 \mathrm{~km}$ to the east of the Peru-Chile trench and 120 to $150 \mathrm{~km}$ above the Benioff-Wadati plane (Barazangi and Isacks 1976). The Nazca plate is being subducted beneath the South American plate with a $\mathrm{N} 80^{\circ}$ trend, a subduction dip in the range of $20-30^{\circ}$, and an average velocity of $4.6 \mathrm{~cm} /$ year (Sébrier and Soler 1991).

The Miocene to Recent volcanic arc in southern Peru consists of composite cones, lava fields, domes, and ignimbrites. Of the Holocene volcanoes, seven have had historical eruptions (Nevado Sabancaya, El Misti, Ubinas, Huaynaputina, Ticsani, Tutupaca, and Yucamane), while others are dormant (Nevado Sara Sara, Nevado Coropuna,
Nevado Ampato, Chachani, and Casiri) (James 1982; de Silva and Francis 1991). Extinct volcanoes, such as Nevado Solimana, Pichu Pichu, Hualca Hualca and many other deeply glaciated volcanoes are of Late Miocene to Early Quaternary age and have not been active in the Holocene.

Central Andean composite volcanoes are built on exceptionally thick crust (ca. $60 \mathrm{~km}$ ) and have lifetimes of more or less 1 million years. Several types of volcanic structures and evolutionary styles are observed. Two typical end-members are: (1) relatively short-lived ( $<0.5 \mathrm{Ma})$, andesite-dacite stratocones with symmetrical shape and central vent. The typical temporal evolution is characterized by rather continuous eruptions of largely similar lava composition. Evidence for frequent magma mixing is observed, either as a volcanic trigger event or, more often, in the petrographic record. (2) Long-lived clusters $(>0.5 \mathrm{Ma})$ of dacitic domes with pyroclastic aprons. Lava compositions are thermally buffered, resulting in low-output volcanoes of rather monotonous compositions. Magma interaction is also recorded in minerals showing complex compositional textures.

In addition to these different evolutionary styles of composite volcanoes, distinct magmatic regimes are also observed. One prominent recorder of magma chamber depth, water content and degree of differentiation is amphibole. "Slower" systems tend to crystallize amphibole at a given $\mathrm{SiO}_{2}$ content compared to the more dynamic and generally more mafic stratocone systems. A rapid change from one regime to another is not normally observed but, in certain cases, e.g., where gravitational collapse has unloaded the edifice and the magmatic system below, a change in regime can be immediate from a "slow" system to one with high magma input, high mix- 
Table 1 Summary of the ${ }^{40} \mathrm{Ar}-{ }^{39} \mathrm{Ar}$ ages of Ubinas rocks; see text for discussion, Figs. 6, 7, and repository data 1-3 for analytical data

\begin{tabular}{|c|c|c|c|c|}
\hline $\begin{array}{l}\text { Sample number } \\
\text { Edifice }\end{array}$ & Location (UTM units, Fig. 2) & $\begin{array}{l}\text { Material or } \\
\text { mineral dated }\end{array}$ & $\begin{array}{l}\text { Accepted Ar-Ar } \\
\text { age ka, } \pm 2 \sigma\end{array}$ & Comment \\
\hline Ubi-120, Ubinas IIa & $\begin{array}{l}\text { Block-lava flow, } 3,600 \text { m, E } 298.5 \text {, } \\
\text { N } 8189.7\end{array}$ & Biotite & $168 \pm 30$ & $\begin{array}{l}\text { Weighted mean from five } \\
\text { single-grain laser fusions }\end{array}$ \\
\hline Ubi-46, Ubinas IIb & $\begin{array}{l}\text { Lava dome, S flank, } 4,100 \mathrm{~m} \text {, } \\
\text { above Querapi, E } 298.1, \mathrm{~N} 8189.3\end{array}$ & Biotite & $250 \pm 26$ & Plateau age, bulk sample \\
\hline Ubi-122, Ubinas IIa & $\begin{array}{l}\text { Lava flow, SSE flank, } 4,850 \mathrm{~m} \text {, } \\
\text { E } 299.9 \text {, E } 8190.1\end{array}$ & $\begin{array}{l}\text { Whole-rock } \\
\text { Amphibole }\end{array}$ & $\begin{array}{l}142 \pm 3 \text { not } \\
\text { available* }\end{array}$ & $\begin{array}{l}\text { Mini-plateau (58\% of the total } \\
{ }^{39} \text { Ar released) Bulk sample }\end{array}$ \\
\hline Ubi-123, Ubinas II & $\begin{array}{l}\text { Lava flow, summit area, } 5,460 \mathrm{~m} \text {, } \\
\text { E } 297.7, \mathrm{~N} 8193.4\end{array}$ & Amphibole & not available* & $\begin{array}{l}\text { Bulk sample (see text for data and } \\
\text { method) *amphibole dates furnish } \\
\text { only maximum ages (not accepted } \\
\text { here; see discussion, Appendix 1) }\end{array}$ \\
\hline
\end{tabular}

Table 2 List of ${ }^{14} \mathrm{C}$ dates related to pyroclastic deposits around Ubinas

\begin{tabular}{|c|c|c|c|c|c|}
\hline $\begin{array}{l}\text { Sample } \\
\text { and Lab number }\end{array}$ & Location UTM (Figs. 2, 6 and 9) & Material & Deposit & $\begin{array}{l}{ }^{14} \mathrm{C} \text { age } \\
\text { (yr B.P.) }\end{array}$ & $\begin{array}{l}\text { Calibrated age } \\
(1 \sigma)\end{array}$ \\
\hline L.S.2, Lv-2183 & $\begin{array}{l}\text { Laguna Salinas S shore, } 4,300 \mathrm{~m} \text {, } \\
\text { E271.5 N 8185.5 }\end{array}$ & Peat & $\begin{array}{l}\text { Peat } 430-445 \mathrm{~cm} \text { deep, } \\
\text { above tephra LS3 }\end{array}$ & $14690 \pm 200$ & Non applicable \\
\hline L.S.3. Lv-2106 & $\begin{array}{l}\text { Laguna Salinas S shore, } 4,300 \mathrm{~m} \text {, } \\
\text { same site }\end{array}$ & Peat & $\begin{array}{l}\text { Peat } 190-200 \mathrm{~cm} \text {, bottom of } \\
\text { section }\end{array}$ & $9700 \pm 190$ & 8325-8802 cal B.C. \\
\hline $\begin{array}{l}\text { Ubi JCT97-3, } \\
\text { GrA-9237 }\end{array}$ & $\begin{array}{l}\text { Road section near Anascapa, } \\
3,400 \text { m, E } 298.7, \text { N } 8186.7\end{array}$ & Charcoal & $\begin{array}{l}\text { Ash layer between two } \\
\text { pumice-fall deposits }\end{array}$ & $7480 \pm 40$ & 6700-7000 cal B.C. \\
\hline $\begin{array}{l}\text { Ubi JCT97-4, } \\
\text { GrN-22820 }\end{array}$ & $\begin{array}{l}\text { Road section nearby Querapi, } \\
3,800 \mathrm{~m} \text {, E } 298.9 \mathrm{~N} 8188.8\end{array}$ & $\begin{array}{l}\text { Organic } \\
\text { matter }\end{array}$ & $\begin{array}{l}\text { Peat and gyttja, base } \\
\text { of a hummock }\end{array}$ & $3670 \pm 60$ & 1938-2136 cal B.C. \\
\hline $\begin{array}{l}\text { Ubi JCT97-1, } \\
\text { GrN-23146 }\end{array}$ & $\begin{array}{l}\text { Tank water above Ubinas } \\
\text { village, } 3,800 \mathrm{~m}, \text { E301.5 } \\
\text { N } 8188.9\end{array}$ & Charcoal & $\begin{array}{l}\text { Ash layer at the contact } \\
\text { of the pumice-fall deposit }\end{array}$ & $980 \pm 60$ & $1000-1164 \mathrm{cal}$ A.D. \\
\hline
\end{tabular}

(GrN and Lv numbers = conventional dates; GrA numbers = AMS dates; Lv University of Louvain; GrN, GrA: J. van der Plicht, Centre for Isotope Research, Rijksuniversiteit, Groningen)

ing and eruption rates (e.g., Volcan Parinacota, Wörner et al. 1988; Bourdon et al. 2000). However, what exactly causes the switch from one regime to another is largely unknown. It is therefore of particular interest to study the recent volcanoes, such as Ubinas, that show such changes in their volcanic and magmatic evolution and to consider how these may relate to the problem of assessing volcanic hazards.

Ubinas volcano in southern Peru is not only one of the historically most active volcanoes in the Central Andes, it has virtually been unstudied (Bullard 1962). Most importantly, Ubinas records a significant change in its eruptive style and magma composition during its recent eruptive history. In order to constrain models of volcano growth and destruction in the Central Andes, changes in eruptive style and magmatic regime, and how these relate to hazards, we aim to characterize the geological and petrological evolution of Ubinas, using geological and geophysical fieldwork, satellite images, major and trace element geochemistry, as well as radiometric datings (Tables 1 and 2). Since Ubinas is the historically most active volcano in southern Peru, its eruptive and magmatic history, the hazard-zone mapping, and geophysical measurements enable us to assess potential volcanic hazards. They are fourfold: fallout from vulcanian, phreatomagmatic or Plinian eruptions; ash- or pumicerich pyroclastic flows; a collapse of the southern flank and subsequent debris avalanches, and; lahars triggered by snowmelt, rainfall or by a debris avalanche. Should a Plinian eruption occur, ash fall may affect one million people living $60 \mathrm{~km}$ west of Ubinas in the area of the city of Arequipa.

\section{Geological setting and structure of Ubinas}

Ubinas is a composite cone with a roughly circular shape (Figs. 2 and 3), which is built on a high plateau formed by Oligo-Miocene ignimbrites of the Llallahui Formation (Tacaza Group) and intrusive rocks of upper Tertiary age (Marocco and del Pino 1966). Late Miocene to Early Quaternary lavas of the Barroso Group form the immediate basement. With an area of $65 \mathrm{~km}^{2}$, the 1,400-m-high cone has a volume of ca. $56 \mathrm{~km}^{3}$. The edifice has been built mainly in Lower-Middle to Late Pleistocene times but has been persistently active to the present. Ubinas is sitting on the NW margin of an erosional NNW-SSEelongated depression (Fig. 2). Large landslides formed amphitheater scars on the high, steep slopes of the western side of the depression. The general trend of the de- 


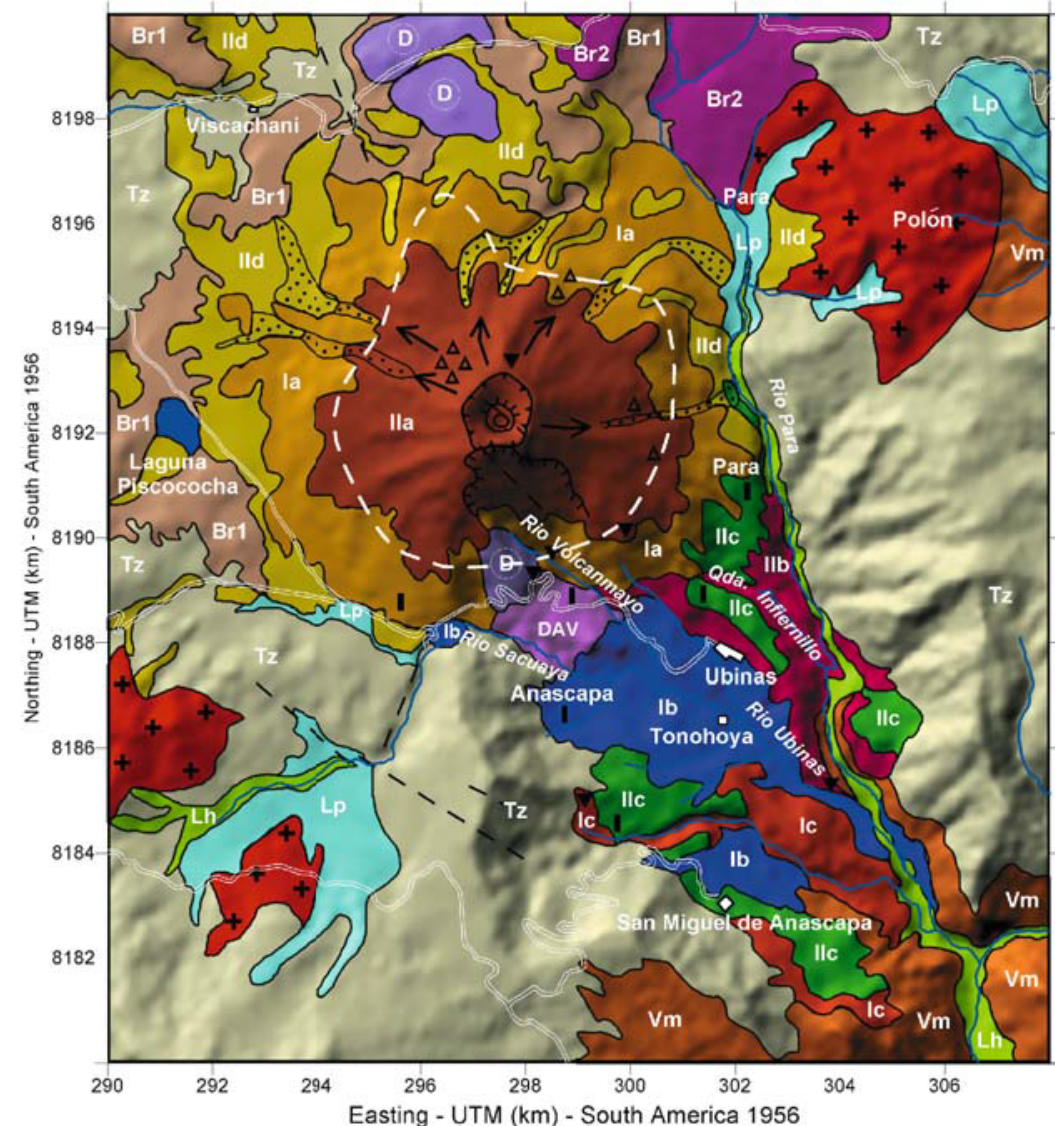

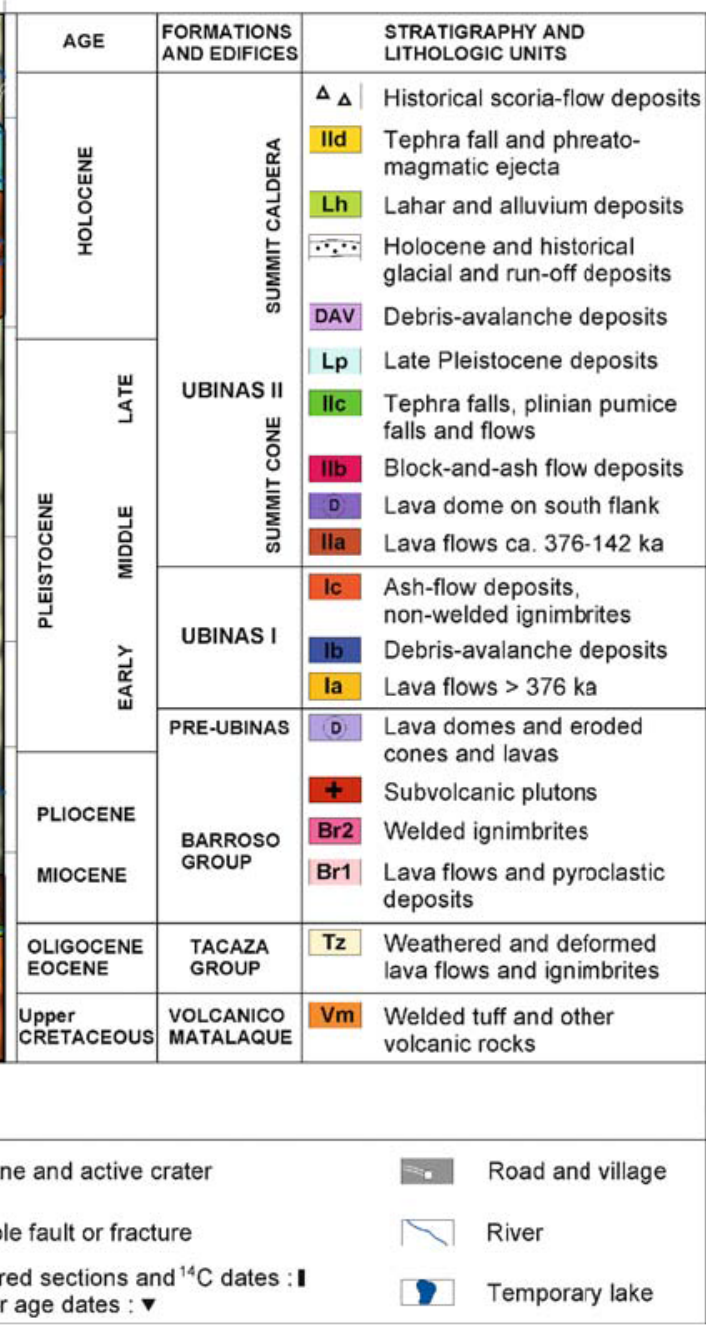

Fig. 2 Schematic geologic map of Ubinas volcano, superimposed on a Topographic Digital Elevation Model, based on field observations, aerial photographs, and on a SPOT satellite image. The

\section{惮 $\mid$ Ash cone and active crater \\ 1. Measured sections and ${ }^{14} \mathrm{C}$ dates : \\ $1 \nabla{ }^{40} \mathrm{Ar} /{ }^{39} \mathrm{Ar}$ age dates : $\boldsymbol{v}$} Boundary of the hydrothermal system based on self-potential measurements Scar of flank failure location of the measured sections and of the ${ }^{14} \mathrm{C}$ and ${ }^{40} \mathrm{Ar}-{ }^{39} \mathrm{Ar}$ dated samples is also shown

formed during the 1991 Pinatubu eruption. The Ubinas caldera walls are 80-300 m high and consist of hydrothermally altered lava flows. The caldera is floored by lava flows and a 20-m-thick pile of lapilli and ash-fall layers, products of frequent, Late Holocene, phreatic and phreatomagmatic eruptions from the small, younger inner crater. The presently active inner crater, $400 \mathrm{~m}$ across and $300 \mathrm{~m}$ deep, has cut through two adjacent ash cones a few tens of meters high above the caldera floor (Fig. 3b). The N140-trending elongated shape parallels fractures crossing the hydrothermally altered wall of the caldera. The bottom of the crater shows persistent (at least since 1995), high-temperature fumaroles $\left(440^{\circ} \mathrm{C}\right.$ in 1998$)$ fed by six vents. The inner crater, close to the south flank (Fig. 3b), which is $<200 \mathrm{~m}$ high, shows a dense pattern of fractures, pervasive hydrothermal alteration, and must be considered gravitationally unstable. maximum diameter of $1.4 \mathrm{~km}$, which may have resulted from a limited amount of funnel-type collapse (after Lipman 1997) and from excavation by medium-scale (1$3 \mathrm{~km}^{3}$ ) Plinian eruptions. Such a summit caldera also 
Fig. 3 a South and SE flanks of Ubinas volcano showing the steep-sided lava flows of Ubinas II, truncated by the summit caldera $1.4 \mathrm{~km}$ across at ca. $5,400 \mathrm{~m}$ a.s.1. The fractured amphitheatre of the S flank overhangs thick ridges built up of pyroclastic-flow deposits. Ubinas village at $3,400 \mathrm{~m}, 6 \mathrm{~km}$ from the vent. b Southern wall of the summit caldera with fractured, hydrothermally altered lavas and young ash cone on the caldera floor with fumaroles escaping from the active crater (photographs by J.C. Thouret 1996-98)
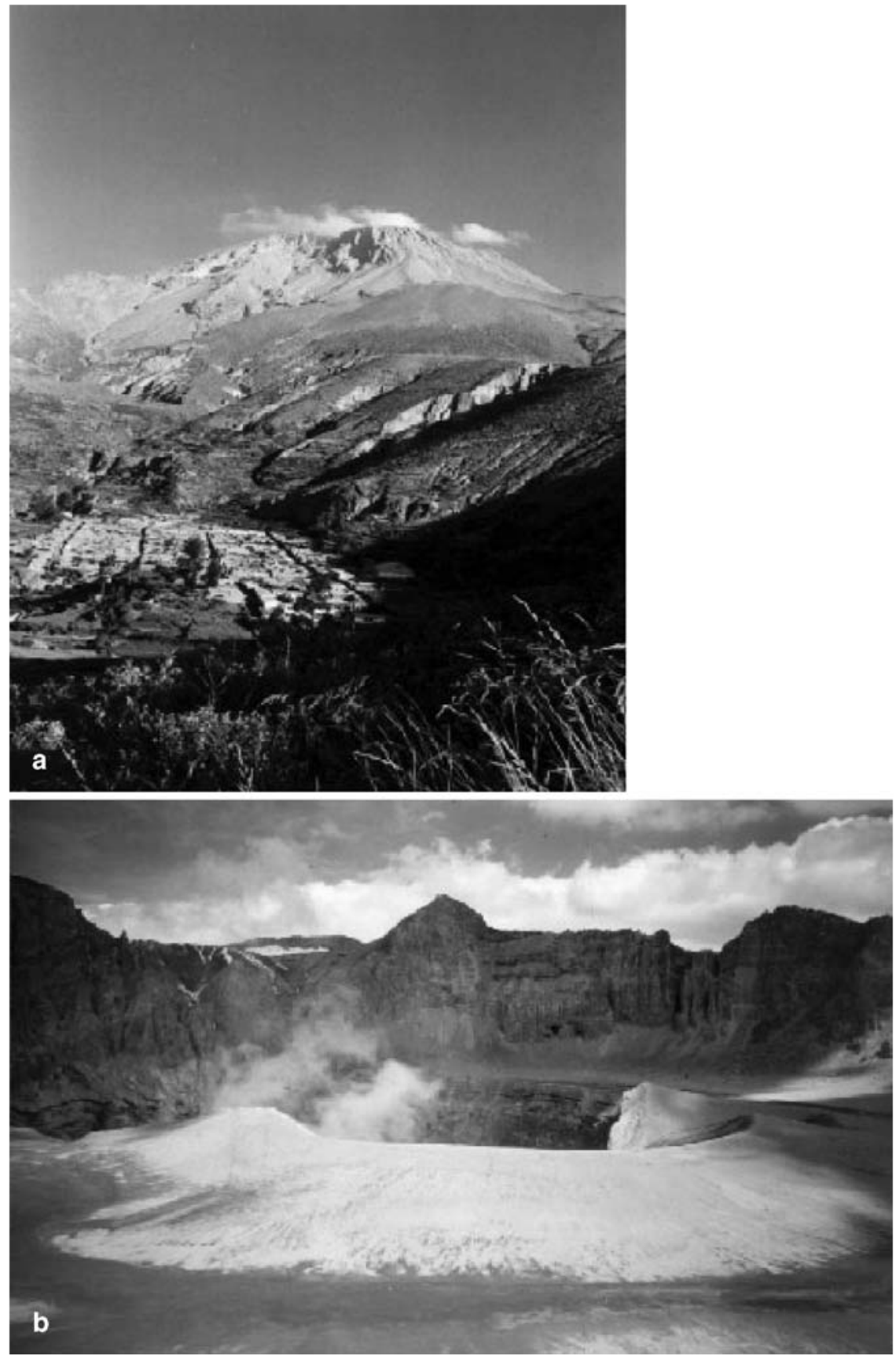

\section{Stratigraphy, geochronology, volcano growth and denudation}

${ }^{40} \mathrm{Ar} /{ }^{39} \mathrm{Ar}$ age data: results and interpretation

A summary of the ${ }^{40} \mathrm{Ar} /{ }^{39} \mathrm{Ar}$ ages is given in Table 1 and Fig. 5. Age spectra for the high-frequency furnace experiments are shown in Fig. 6. All errors are presented at $2 \sigma$. Details of sample preparation, dating method, and the full ${ }^{40} \mathrm{Ar} /{ }^{39} \mathrm{Ar}$ data set are given in the Data Repository.

Amphibole separates (Ubi 122 and Ubi 123) show disturbed saddle shaped spectra (Fig. 6a, b) probably induced by excess argon. The minimum ages of $335 \pm 50$ and
$378 \pm 38 \mathrm{ka}$ thus indicate a maximum age for the amphiboles Ubi 122 and Ubi 123, respectively. The ${ }^{37} \mathrm{Ar}$ $\mathrm{Ca}^{39}{ }^{\mathrm{Ar}_{\mathrm{K}}}$ ratio of the amphiboles Ubi 122 and Ubi 123 is constant at intermediate and high temperatures indicating that the intermediate minimum age might represent the degassing of pure amphibole.

The additional experiment with the whole-rock sample of Ubi 122 shows a small "plateau area" of 4 steps from 750 to $900^{\circ} \mathrm{C}$, representing $58 \%$ of the total ${ }^{39} \mathrm{Ar}$ released (Fig. 6c). The age of $142 \pm 3 \mathrm{ka}$, which results from temperatures lower than the amphibole-degassing peak, may represent the best estimate of the age of the Ubi 122 lava flow. However, the steps included in the plateau calcu- 
Fig. 4 Composite lithostratigraphic sections showing the geologic and volcanic evolution of Ubinas volcano: a Pre-Ubinas basement and Ubinas I stratovolcano. b Ubinas II summit cone

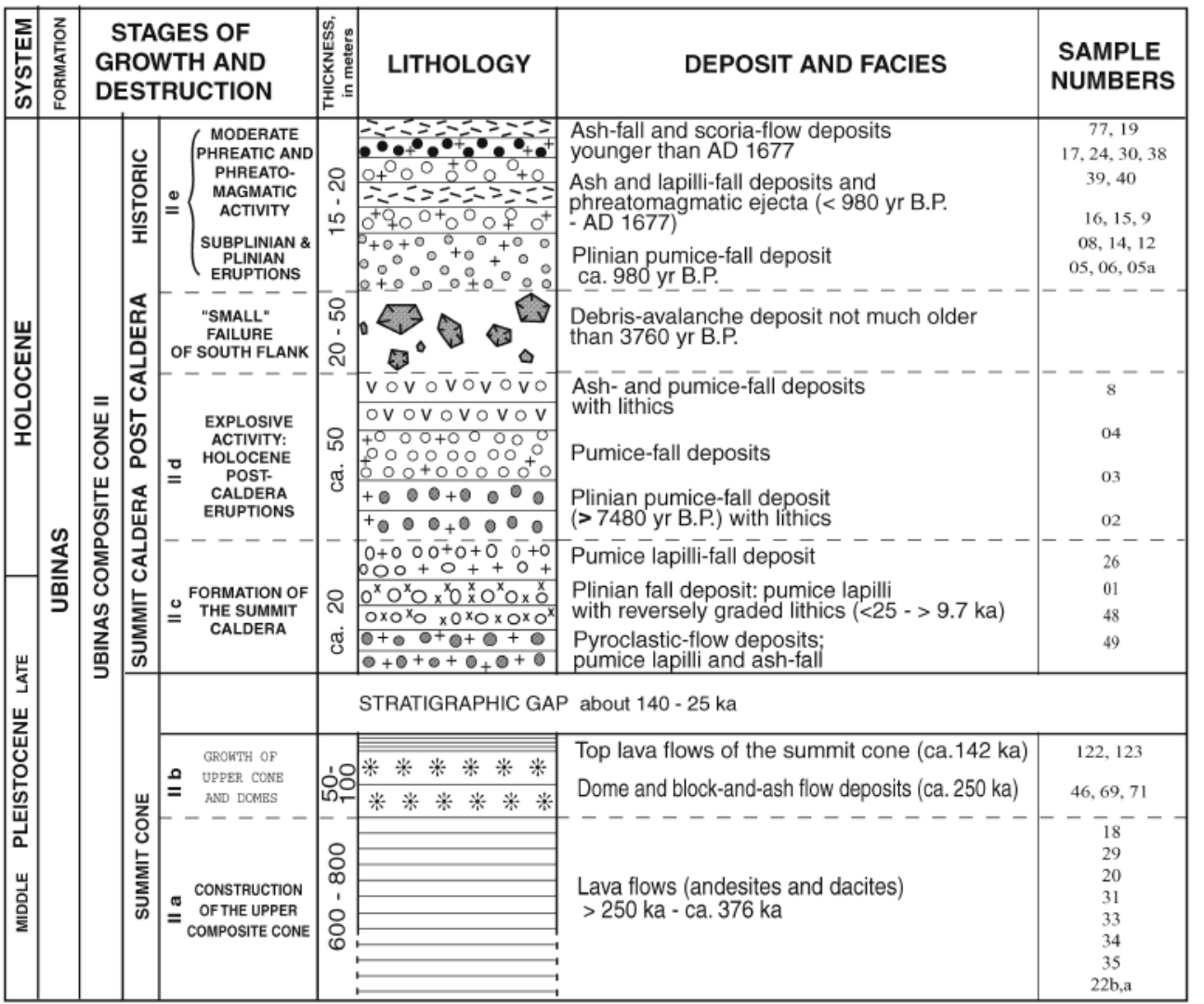

\begin{tabular}{|c|c|c|c|c|c|c|}
\hline & & & & & & \\
\hline $\begin{array}{l}\sum_{m}^{5} \\
\frac{5}{\omega} \\
\omega\end{array}$ & 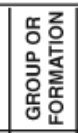 & $\begin{array}{l}\text { STAGES OF } \\
\text { GROWTH AND } \\
\text { DESTRUCTION }\end{array}$ & 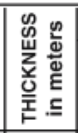 & $\begin{array}{c}\text { STRATIGRAPHY } \\
\text { AND } \\
\text { LITHOLOGY }\end{array}$ & DEPOSIT AND FACIES & 음 \\
\hline & & Ic Opening of a small & . $E$ & $\begin{array}{llll}\mathrm{v} & \mathrm{v} & \mathrm{v} & \mathrm{v} \\
\end{array}$ & Non-welded ignimbrite (ash & די \\
\hline 宸 & & summit caldera & స్లి & $\begin{array}{|cccc|}\mathrm{V} & \mathrm{V} & \mathrm{v} & \mathrm{v} \\
\mathrm{v} & \mathrm{v} & \mathrm{v} & \mathrm{v}\end{array}$ & and pumice flows) and breccia & 128 \\
\hline 足 & 岁 & $\begin{array}{l}\text { Sector collapse } \\
\text { to the south }\end{array}$ & $\begin{array}{l}80- \\
120 \\
\end{array}$ & $\theta_{\theta} \theta_{0} \Leftrightarrow \vec{\Delta}$ & Ubinas I debris-avalanche deposit & 120 \\
\hline$\frac{D}{a}$ & 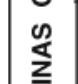 & Ia Construction of the & 8 & & Lava flows (andesites and & $\begin{array}{l}42 \\
43 \\
82\end{array}$ \\
\hline 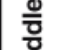 & $\stackrel{m}{g}$ & base of the composite & 8. & $\bullet \cdot \bullet$ & Minor amount of breccias and & $\begin{array}{l}79 \\
36\end{array}$ \\
\hline $\bar{\Sigma}$ & & & & $\bullet \cdot \bullet$ & pyroclastic deposits & $\begin{array}{c}1 \\
10\end{array}$ \\
\hline$\sum_{\mathrm{u}}^{\mathrm{u}}$ & 용 & Barroso Group & ஓ &  & Lava flows (andesites) & \\
\hline$\frac{0}{9}$ & $\frac{\tilde{c}}{\frac{\pi}{\alpha}}$ & $\begin{array}{c}\text { Volcanic Arc } \\
\text { Chila and Sencca Fms }\end{array}$ & ฉั่ & $\begin{array}{rl}v & v \\
\end{array}$ & Lava flows and tuffs (rhvolite) & \\
\hline ò & MAURE & $\begin{array}{c}\text { Lake and volcaniclastic } \\
\text { sedimentation }\end{array}$ & $\begin{array}{l}100- \\
150\end{array}$ & 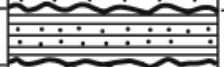 & $\begin{array}{l}\text { Lacustrine sediments and } \\
\text { reworked tuffs }\end{array}$ & \\
\hline 岁 & 윽 & \begin{tabular}{|c|} 
subvolcanic plutons \\
(rhyolite and andesite)
\end{tabular} & & & & \\
\hline 岩 & ర్జ & Llallahui Fm. & & $\mathrm{v}$ & & \\
\hline 售 & $\mathbb{4}$ & Volcanic Arc & స్ & & Lava flows & \\
\hline 孚 & ర్屯 & (deformed and & ठ். & $\times \mid \begin{array}{llll}0 & 0 & 0 & 0 \\
0 & 0 & 0 & 0\end{array}$ & Volcanic breccia & \\
\hline 岁 & & & & $\mid x v_{v} \begin{array}{lllll}v & v & v & v \\
V\end{array}$ & $\begin{array}{c}\text { Tuffs } \\
\text { Lava flows (andesites) }\end{array}$ & \\
\hline 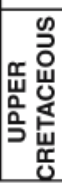 & 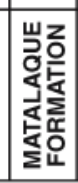 & $\begin{array}{l}\text { Volcanics (deformed } \\
\text { and faulted) and } \\
\text { volcaniclastic } \\
\text { sedimentation }\end{array}$ & $\begin{array}{l}8 \\
\vdots \\
\dot{o}\end{array}$ & 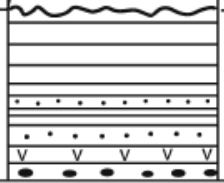 & $\begin{array}{l}\text { Lava flows (andesites) } \\
\text { volcaniclastic deposits, } \\
\text { continental sediments }\end{array}$ & \\
\hline
\end{tabular}

b 
$\begin{array}{lllllllllll}0 & 50 & 100 & 150 & 200 & 250 & 300 & 350 & 400 & 450 & 500\end{array}$

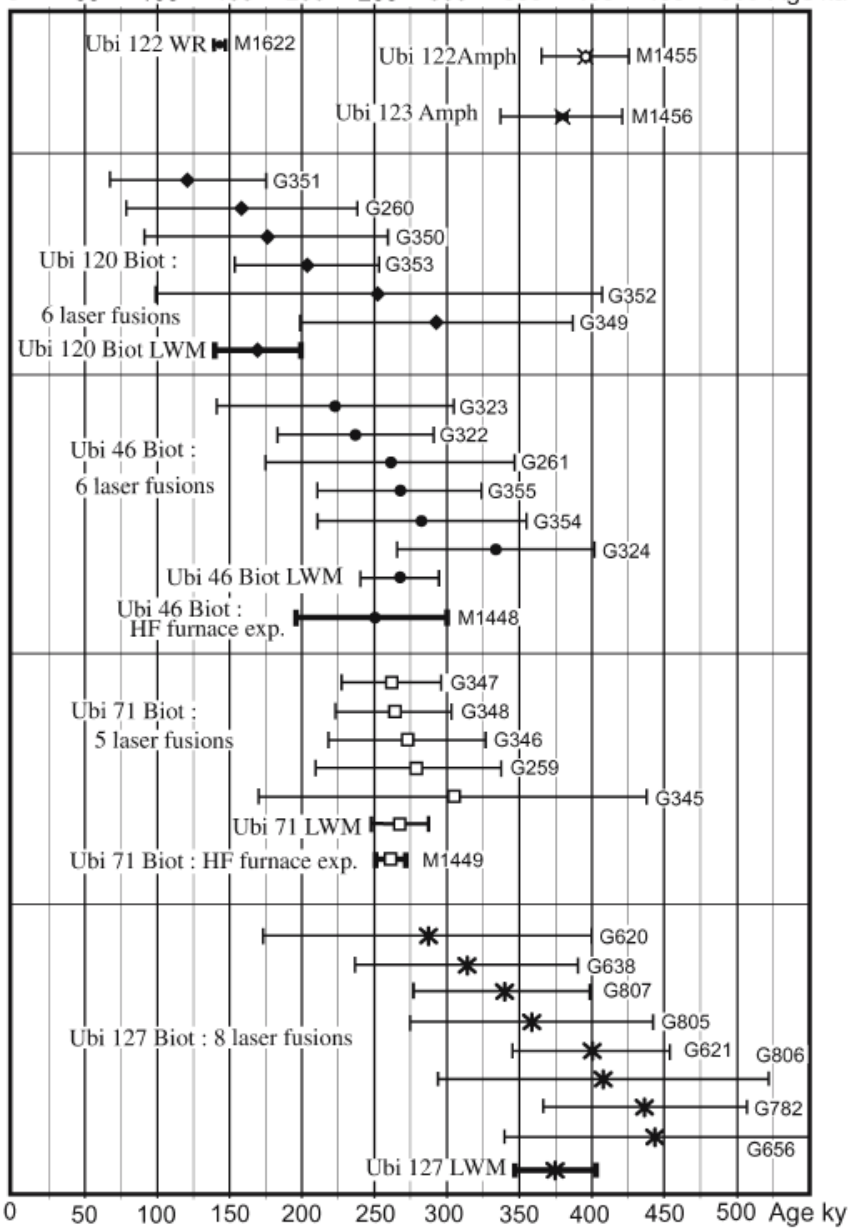

Fig. 5 Plot of the measured ages on Ubinas samples (error bar at the $2 \sigma$ confidence level). Heading letter in the experiment number refers to laser experiment $(G)$ or to HF furnace experiment $(M)$. Preferred ages are based on HF furnace experiment for Ubi 123, Ubi 46 and Ubi 71, and on the weighed mean ( $L W M)$ of the laser experiments for Ubi 120 and Ubi 127. Note that the amphibole ages are maximum ages, which are not reliable when compared to the available stratigraphy

lation show a slight decrease of apparent ages with increasing temperatures, which may indicate that some recoil is present with excess argon at the higher $\left(>1,100^{\circ} \mathrm{C}\right)$ temperature steps (induced by the amphiboles?).

Biotite bulk sample Ubi 71 yields a plateau age of $261 \pm 10 \mathrm{ka}$ (Fig. 6d). The plateau includes six steps from 1,010 to $1,250^{\circ} \mathrm{C}$ representing $88 \%$ of the total ${ }^{39} \mathrm{Ar}$ released. This age is concordant with the age of $261 \pm 8 \mathrm{ka}$ calculated with the same steps plotted on an isotopic correlation diagram of ${ }^{36} \mathrm{Ar} /{ }^{40} \mathrm{Ar}$ vs. ${ }^{39} \mathrm{Ar} /{ }^{40} \mathrm{Ar}$. The data yield a linear correlation with a MSWD of 1.4 and an initial trapped atmospheric $\mathrm{Ar}$ with a ${ }^{40} \mathrm{Ar} /{ }^{36} \mathrm{Ar}$ ratio of $294.9 \pm 1.5$, indicating that no excess argon is present. This age is also concordant at the $2 \sigma$ level with each fusion age of five single-grain laser experiments and the corresponding weighted mean of $269 \pm 20 \mathrm{ka}$. The plateau age of $261 \pm 10 \mathrm{ka}$ is probably reliable.
Biotite from Ubi 46 yields a plateau age of $250 \pm 26 \mathrm{ka}$ (Fig. 6e). The plateau includes six steps from 1,100 to $1,450^{\circ} \mathrm{C}$ representing $85 \%$ of the total ${ }^{39} \mathrm{Ar}$ released. This age is concordant with the age of $251 \pm 14 \mathrm{ka}$ calculated from the same steps on a ${ }^{36} \mathrm{Ar} /{ }^{40} \mathrm{Ar}$ vs. ${ }^{39} \mathrm{Ar} /{ }^{40} \mathrm{Ar}$ diagram. The data yield a linear correlation with a MSWD of 1.1 and an initial trapped $\mathrm{Ar}$ with ${ }^{40} \mathrm{Ar} /{ }^{36} \mathrm{Ar}=292.7 \pm 2.6$. This age is also concordant at the $2 \sigma$ level with each fusion age of six single-grain laser experiments and with the corresponding weighted mean of $266 \pm 28 \mathrm{ka}$. The plateau age of $250 \pm 26 \mathrm{ka}$ is probably reliable.

Eight biotite single-grain laser step-heating experiments were made on the sample Ubi 127. The atmospheric contamination remained above $90 \%$ for all the temperature steps. The ${ }^{39} \mathrm{Ar}$ degassing occurred during the low temperature steps and the fusion step represented only a small fraction of the total ${ }^{39} \mathrm{Ar}$ released. Thus, based on the experiments G638, G656, G782, and G805, a plateau age is used. During these experiments, isotopic correlation diagrams indicated initial ${ }^{40} \mathrm{Ar} /{ }^{36} \mathrm{Ar}$ near atmospheric composition from 293.8 to 297.2. Ages ranging from $288 \pm 114$ to $444 \pm 106 \mathrm{ka}$ agree within the analytical uncertainty of $2 \sigma$ level (Fig. 5). The weighed mean age of $376 \pm 27$ ka may represent a reliable age for Ubi 127.

Six biotite single-grain laser step-heating experiments were performed on the sample Ubi 120 . The fusion step ages vary between $120 \pm 27$ and $292 \pm 47 \mathrm{ka}$. Two age-data are not concordant (G351 and G349; when we reject the G349 experiment (which has a large error bar, probably due to alteration), the other five age data are concordant, with a weighted mean of $168 \pm 30 \mathrm{ka}$ that may represent the best age estimate for Ubi 120 . This age is not very different from the weighted mean of the six grains, i.e., $180 \pm 29 \mathrm{ka}$.

Growth and partial destruction of Ubinas I

(Middle Pleistocene)

\section{Stage Ia: Base of the stratovolcano}

The Ubinas Ia period was essentially effusive and produced an estimated 600 to 700 -m-high volcano, mainly built up by andesite to dacite block-lava flows that today cover an area of $65 \mathrm{~km}^{2}$ (Figs. 2 and $4 \mathrm{a}$ ). Based on geologic mapping and on the ${ }^{40} \mathrm{Ar}-{ }^{39} \mathrm{Ar}$ age of one ignimbrite of stage Ic (Table 1, Figs. 5, 6), this period preceded $376 \pm 27 \mathrm{ka}$.

\section{Stage Ib: Sector collapse}

During the second stage $\mathrm{Ib}$, a sector collapse of the Ubinas I edifice has left a large horseshoe-shaped amphitheater open towards the SSE. Resulting debris-avalanche deposits of a volume of about $2.8 \mathrm{~km}^{3}$ were channeled in the Rio Para and Ubinas valleys (Fig. 2). The thickness of the debris-avalanche deposits exceeds 
Fig. $6{ }^{40} \mathrm{Ar} /{ }^{39} \mathrm{Ar}$ ages and ${ }^{37} \mathrm{Ar}_{\mathrm{Ca}} / 39 \mathrm{Ar}_{\mathrm{K}}$ ratio spectra obtained on $\mathrm{HF}$ furnace heating experiment for the Ubinas volcano. See text for discussion. $P$ plateau age; arrows show the steps included in the plateau age calculation. Error on plateau age are given at $\pm 2 \sigma$; the thickness of each apparent age is at $1 \sigma$ level (analytical data are given in Data Repository 2, location of samples is shown in Data Repository 1)
玄
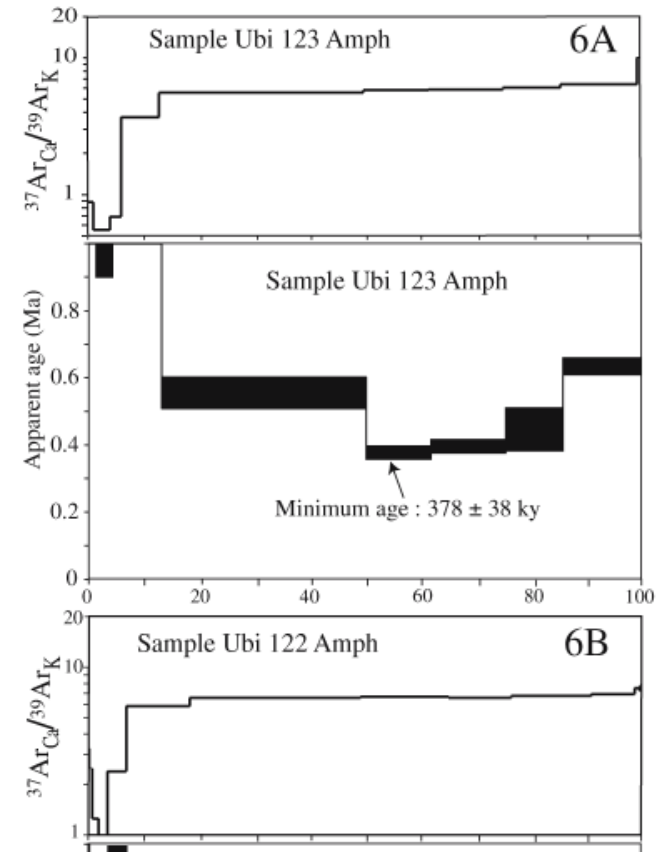

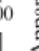
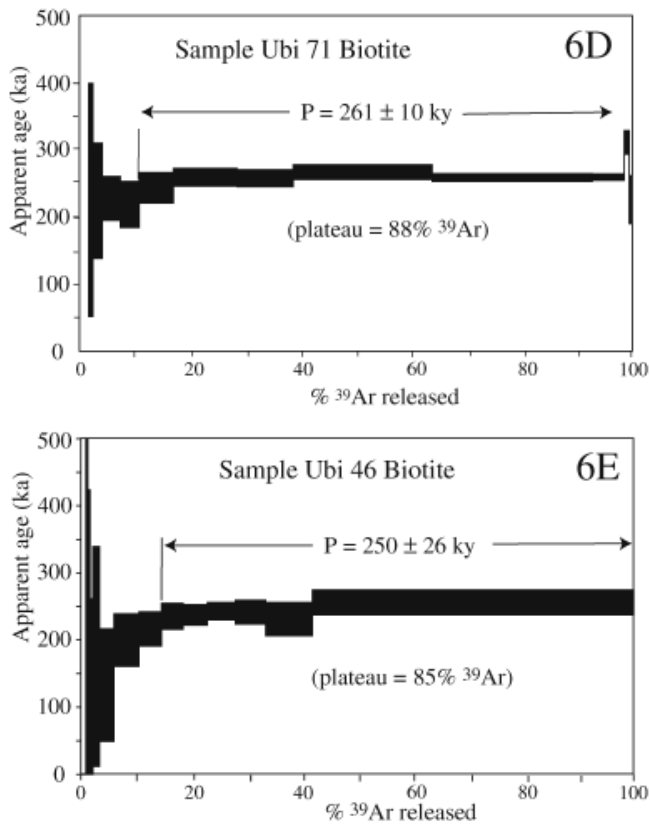

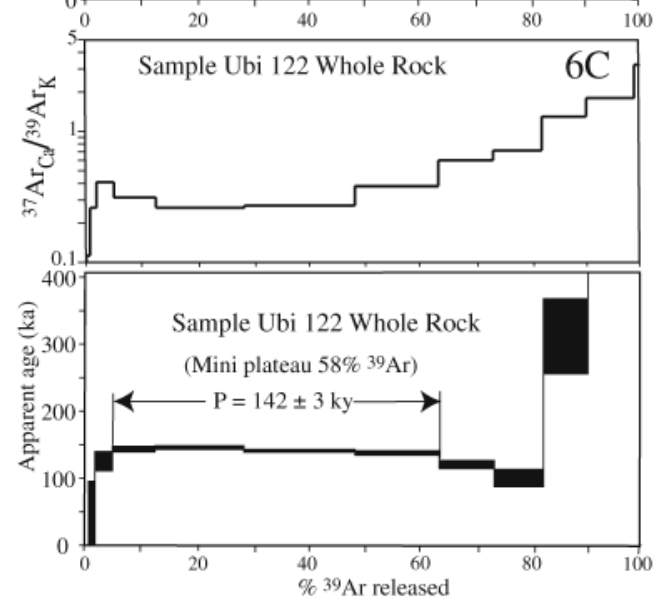

$220 \mathrm{~m}$ at a distance of $4 \mathrm{~km}$ to the SE but decreases to $30 \mathrm{~m}$ at $10 \mathrm{~km} \mathrm{SE}$ of the summit. The debris-avalanche deposits comprise lava blocks several meters in size, often hydrothermally altered and showing jigsaw fractures. Very large blocks of lava $(50-100 \times 10-20 \mathrm{~m})$ from Ubinas I and from the Barroso basement are included in the debris-avalanche deposit at ca. 3,600 m a.s.l. Although difficult to date with accuracy, the sector collapse may have occurred during the stage I (Middle Pleistocene), not long before $376 \mathrm{ka}$ (Table 1).

\section{Stage Ic: A collapse caldera?}

A succession of non-welded, dacitic ash- and-pumice flow deposits with a total volume of ca. $1.8 \mathrm{~km}^{3}$ was emplaced during stage Ic. These deposits are 80-120 m thick at 5-8 km from the base of the south flank (Figs. 2 and 3a) and overlie the debris-avalanche deposits of stage Ib. The pyroclastic flows encompass at least five massive units, which are characterized by abundant $\mathrm{cm}$ - to dmsized accidental andesite clasts. The voluminous, lithicrich pyroclastic-flow deposits suggest the formation of a summit collapse caldera before the Ubinas II edifice, i.e., 
around $376 \pm 27 \mathrm{ka}$, the age of Ubi 127 pumice flows (Table 1) and well before $261 \pm 10 \mathrm{ka}$ (Ubi 71 biotite), i.e., the age of the Ubinas IIa lava flows. Unconformities along with break in slopes at the contact of the lava flows of Ubinas I with those of Ubinas II are visible on the south and southeast flanks of the volcano at 4,800$5,200 \mathrm{~m}$ a.s.1.

Ubinas II (from Middle-Late Pleistocene to historical times)

\section{Stage IIa: Summit cone and lava flows}

A thick series of andesite and dacite block-lava flows forms the present summit cone from 4,800 to more than $5,600 \mathrm{~m}$ a.s.l. (Figs. 2 and 3). One lava flow at 5,500 m yielded a whole-rock age of $142 \pm 3$ ka (Ubi 122). The largest part of the summit cone Ubinas II may be comprised between $<376$ and 142 ka (Table 1, Data Rep. 1). Two ${ }^{40} \mathrm{Ar}-{ }^{39} \mathrm{Ar}$ ages of $261 \pm 10 \mathrm{ka}$ and $168 \pm 30 \mathrm{ka}$ were obtained on block-lava flows (biotite, Ubi- 71 and 120: Table 1, Figs. 5, 6, Data Rep. 1, 2), which form a broad ridge between the valleys of Rio Ubinas and Rio Para. The steep $\left(>30^{\circ}\right)$ lava flows are $20-40 \mathrm{~m}$ thick and have flowed $3-4 \mathrm{~km}$ around the crater on Ubinas I lava flows (Fig. 3a).

\section{Stage IIb: Dome(s) on the south flank}

A large dacitic lava dome $300 \mathrm{~m}$ high grew to a height of $4,100 \mathrm{~m}$ a.s.l. on the south flank of Ubinas and gave an age of $250 \pm 20$ ka (biotite of Ubi 46: Table 1, Figs. 5 and 6, Data Rep. 1). Block-and-ash flows filled up the Rio Ubinas valley to $60 \mathrm{~m}$ as far as $7 \mathrm{~km}$ to the SE of the volcano (Fig. 2). These deposits consist of decimetersized lava blocks in a gray ash matrix. The pyroclastic deposits of stage IIb reflect a period of dome growth and dome destruction at least on the south, SW and SE flanks of the Ubinas II edifice.

\section{A gap in activity from $<142 \mathrm{ka}$ to about $25 \mathrm{ka}$ ?}

The youngest block-lava flows of the Ubinas II summit cone were dated at $168 \pm 30$ (Ubi 120) and $142 \pm 3 \mathrm{ky}$ (Ubi122; see Table 1, Figs. 5 and 6, Data Rep. 1,2) indicating a gap in eruptive activity between $<142 \mathrm{ky}$ and ca. $25-$ $14.7 \mathrm{ky}$ (Fig. 4b), although rocks of that age can be there but not exposed. The lower limit of the gap is constrained by the ${ }^{14} \mathrm{C}$ age of the Ubinas pumice-fall deposits in the Laguna Salinas core (Fig. 8, Table 2).

We cannot entirely exclude that the gap is due to the lack of adequately dated deposits. However, lavas and pyroclastic deposits, which would span the gap, could not have been completely eroded away. Easily eroded Plinian deposits should at least have been preserved in distal stratigraphic sections, but this was not observed. The reason for such a long gap in eruptive activity remains poorly understood. The summit caldera-forming Plinian eruptions, involving the most evolved rhyolitic magmas, occurred when the eruptive activity resumed some 25 14.7 ky ago.

\section{Stage IIc: formation of the summit caldera}

At least four ash-flow deposits underlie Holocene tephra at Quebrada Infernillo $6 \mathrm{~km} \mathrm{SE}$ from the crater. These massive 2 to 4-m-thick ash-flow deposits are comprised of $\mathrm{cm}$-sized dacite pumice and lithic clasts. The oldest ash-flow deposits should not be older than ca. 25-21 ky because they are preserved on steep slopes, in deep gullies (e.g., Qda. Infernillo), and on the flanks of the volcano above 3,800 m a.s.1., which have been, at least partly, eroded by glaciers during the most recent Last Glacial Maximum (before $21 \mathrm{ky}$, Seltzer 1990). The previous stage IIa summit cone was obviously ice clad because the volcano's flanks show glacially shaped headvalleys as well as cirques and moraines at the base of the cone at locations as low as $4,000 \mathrm{~m}$ a.s.l. These glacial features suggest that an ice cap existed large enough to feed glaciers down to the base of the cone.

Although the precise age of the formation of the summit caldera remains poorly constrained, it must have occurred between $25 \mathrm{ky}$ and before $9.7 \mathrm{ky}$ based on Plinian pumice-fall deposits and on tephra correlations (Figs. 7 and 8):

1. At the base of the thick Holocene tephra section $9 \mathrm{~km}$ south of the summit, a 3.8-m-thick coarse-grained Plinian pumice-fall deposit with reversely graded lithics is older than $7.5 \mathrm{ky}$. This is the ${ }^{14} \mathrm{C}$ age (GrA9237, Table 2) of a pumice-fall layer in the section $1.20 \mathrm{~m}$ above it (Fig. 7). The lack of a soil within the tephra suggests that this deposit is probably Lateglacial in age.

2. At least four pumice-fall layers $3.1 \mathrm{~m}$ thick have been found $4 \mathrm{~km} \mathrm{~W}$ of Laguna Salinas and $30 \mathrm{~km}$ WSW of Ubinas (Fig. 8). These are older than $14.69 \pm 0.29 \mathrm{ky}$ (i.e., the age of the base of the peat cored in the Laguna Salinas, above the four pumice layers: Juvigné et al. 1997) and younger than the Last Glacial Maximum 25-21 ky ago (Seltzer 1990).

3. A pumice-fall layer, at least $1.2 \mathrm{~m}$ thick, consists of dacitic pumices and abundant, dense, juvenile lithic clasts. Non vesicular, vitreous clasts with radial fractures, curviplanar surfaces, and cauliflower shapes reflect the effects of phreatomagmatic explosions. The pumice fall has been correlated with a tephra layer (TP2) at Laguna Salinas, which is $45 \mathrm{~cm}$ thick, rich in lithics of similar texture, and slightly older than ca. 14.69 ky (Juvigné et al. 1997; Fig. 8).

4. A 1-m-thick tephra layer of white dacitic lapilli and coarse ash with very rare lithics is observed on top of the section and correlates with a tephra layer (LS3) in the peat core drilled in Laguna Salinas (Fig. 8). This tephra layer is slightly older than $9.7 \pm 0.19 \mathrm{ky}$. 

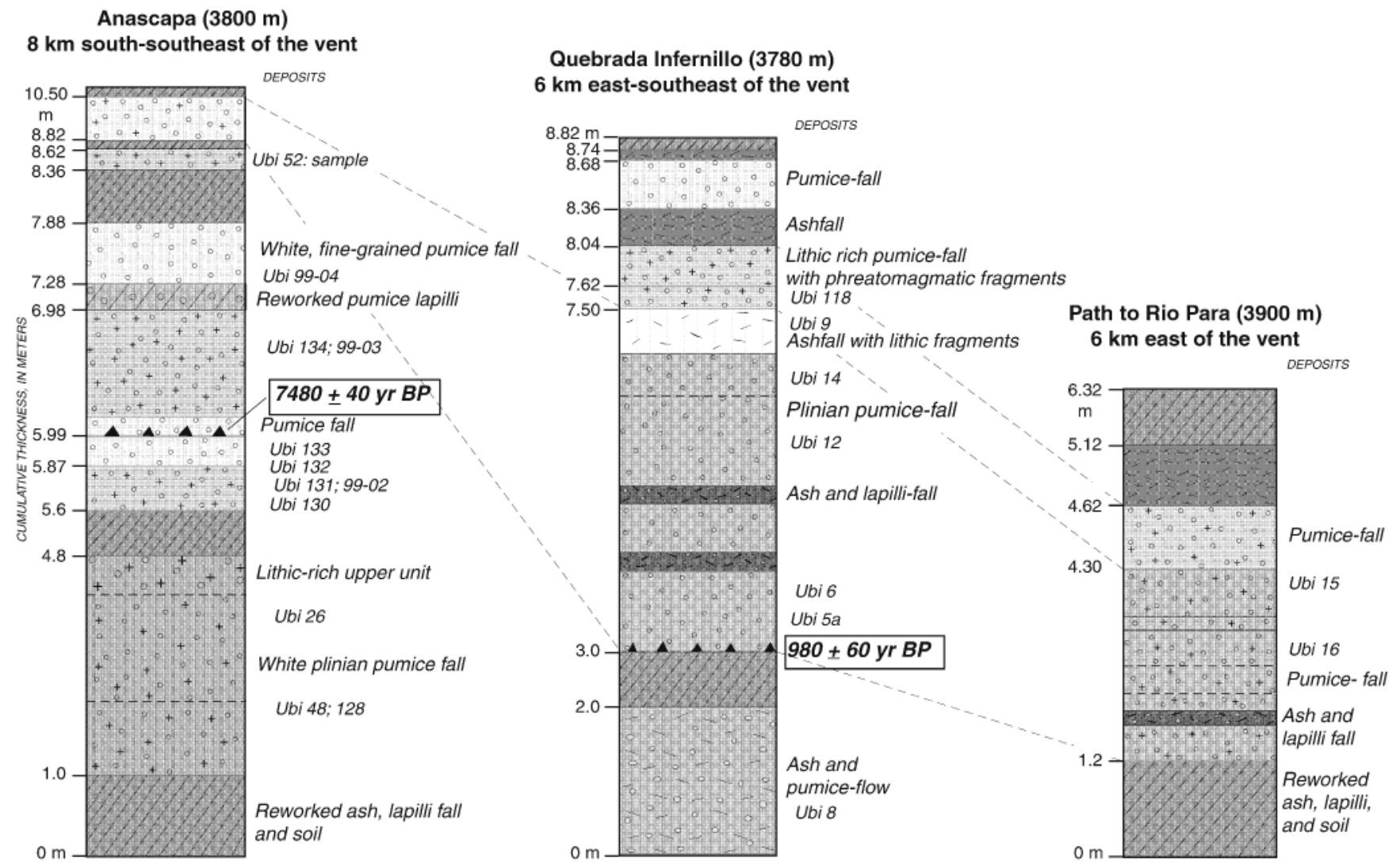

Fig. 7 Composite stratigraphic sections of Late Pleistocene (Late Glacial) and Holocene tephra-fall deposits around Ubinas

Thus, during its most recent history between ca. 25 and $9.7 \mathrm{ky}$, Ubinas produced a series of Plinian eruptions with a volume of 1 to $2 \mathrm{~km}^{3}$. The summit caldera was formed and truncated the Ubinas II cone above $5,380 \mathrm{~m}$ a.s.l. (Figs. 2 and 3a). The pumice-fall deposits can be correlated to locations as far as $35 \mathrm{~km}$ toward the $\mathrm{SW}, \mathrm{S}$ and SE (Figs. 2, 7, and 8), and at least $15 \mathrm{~km}$ away NE of the summit.

\section{Stage IId: Post-caldera eruptions and unstable south flank}

Over the past 7,500 years, the eruptive behavior of Ubinas volcano has consisted of small to medium-scale subPlinian, phreatomagmatic and vulcanian eruptions (Fig. 4b). Flank failures and rockslides occurred on the unstable, $>45^{\circ}$ steep southern flank during the Holocene (Fig. 3a). Hummocks which support the hamlet of Querapi at the base of the south flank as far as $4.5 \mathrm{~km}$ from the summit are witnesses to a debris avalanche event that left a deposit of ca. $1 \mathrm{~km}^{3}$ (Fig. 2). Hummocks, which are 40 to $80 \mathrm{~m}$ high, consist of fractured lava blocks 1 to $10 \mathrm{~m}$ in diameter, often hydrothermally altered and of diverse composition and texture, and cobbles in a coarse matrix.

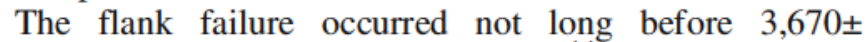
60 yrB.P. (GrN-22820) based on the ${ }^{14} \mathrm{C}$ age of a peat at the base of the debris-avalanche deposit nearby Querapi at ca. 4,000 m a.s.l. (Table 2).

\section{Stage II e: prehistoric and historic eruptions}

One Plinian eruption, dated ca. $980 \pm 60$ year B.P. (A.D. $1000-1160$, Table 2), produced ca. $1 \mathrm{~km}^{3}$ of pumice (Fig. 5). The tephra fall consists of reversely graded, cmto $\mathrm{dm}$-sized andesite pumice and $\mathrm{cm}$-sized lithic clasts. Two layers with ash-coated lapilli and ash particles, intercalated between 60 and $100 \mathrm{~cm}$ above the base of the deposit, witness to two phreatic events during the Plinian eruption. The entire Plinian sequence, which is $4.5 \mathrm{~m}$ thick at $6 \mathrm{~km}$ and $25 \mathrm{~cm}$ thick at $40 \mathrm{~km}$ SE from the summit, has a volume of ca. $2.8 \mathrm{~km}^{3}$. It is overlain by two 60 and $80-\mathrm{cm}$-thick beds of pumice lapilli and lithic clasts at $6 \mathrm{~km}$ SE from the summit. The dense lithic juvenile clasts, with vitreous curviplanar surfaces and chilled margins with radial fractures, suggest phreatomagmatic events.

Ashfall deposits less than $0.1 \mathrm{~km}^{3}$ in volume were emplaced by abundant small (VEI $\leq 2)$ phreatic, phreatomagmatic, and vulcanian eruptions during the past 980 years. Many tephra layers on the caldera floor and in the crater walls consist of gray and yellowish ash, lithic clasts and scattered dm-sized blocks, sometimes hydrothermally altered, with few pumice lapilli (Fig. 3b). In 


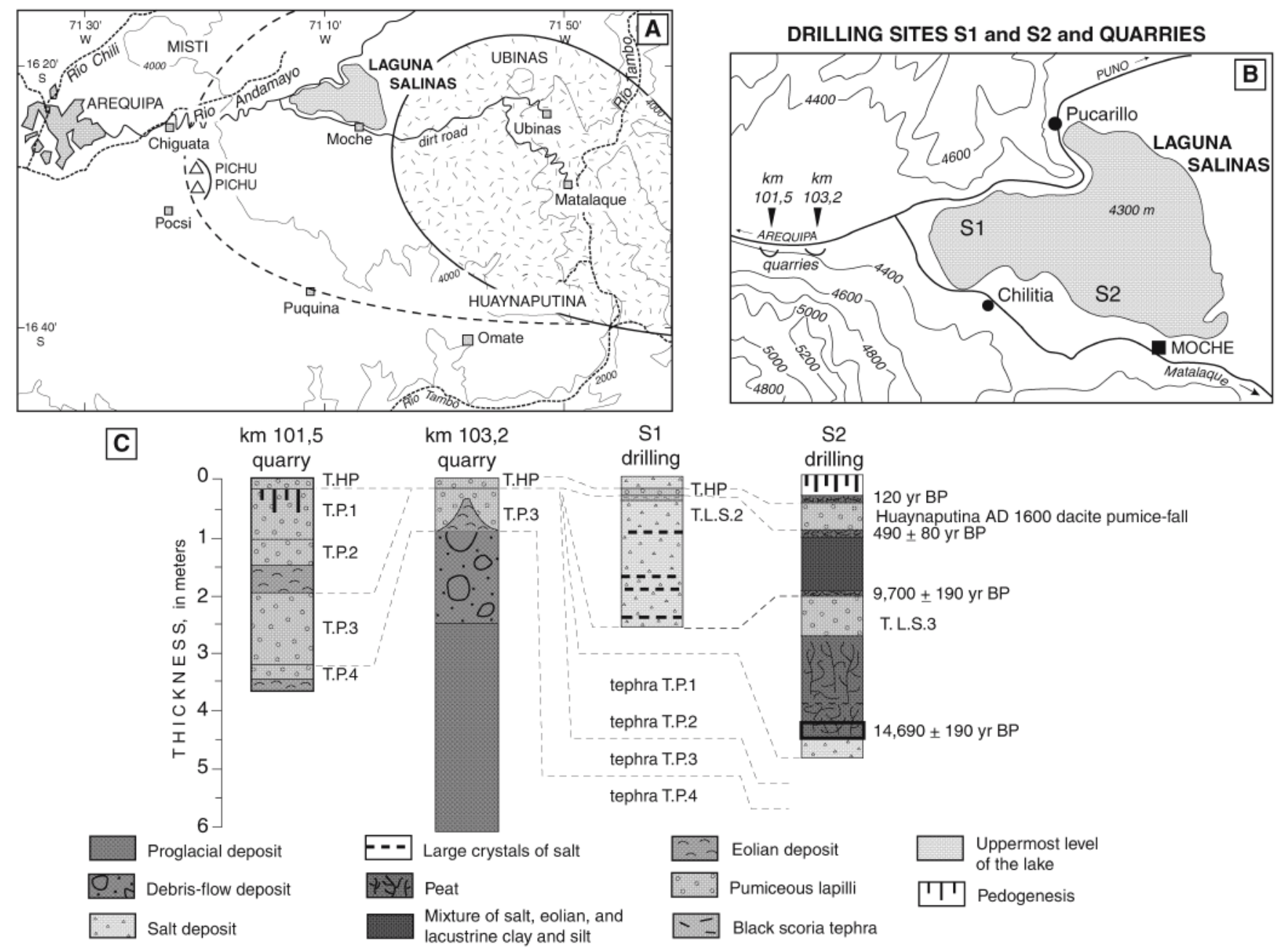

Fig. 8 A Laguna Salinas, a brine lake (salar) acts as a sediment trap at 4,300 m a.s.1. in a volcano-tectonic depression $35 \mathrm{~km}$ east of Arequipa. The stippled area was mantled by at least $50 \mathrm{~cm}$ of pumice lapilli-fall deposit during the Holocene. The dashed line west of Laguna Salinas shows the possible reach of a $10+\mathrm{cm}$-thick Plinian pumice-fall deposit from Ubinas due to prevailing eastern

addition, yellowish-orange, hydrothermally-altered lithic and pumice lapilli cover Ubinas' flanks and the Altiplano surrounding the edifice as far as $15 \mathrm{~km}$ towards the west and NE (Figs. 2 and 3). Lapilli $1-2 \mathrm{~cm}$ in diameter mantle the volcano's flanks as far as $5 \mathrm{~km}$ around the summit.

Preserved deposits, chronicles, and witness accounts all indicate that no less than 23 eruptive events, including fumarolic episodes, have occurred since 1550 . Therefore Ubinas is the most active volcano in southern Peru, with three to five events per century (Hantke and Parodi 1966; Simkin and Siebert 1994; Valdivia 1995; Rivera et al. 1998). Most of them were small events and even the dark gray, mafic ash- and scoria-flow deposits of A.D. 1677 (VEI 3: Simkin and Siebert 1994) are poorly preserved on the uppermost flanks of Ubinas II (Fig. 2). The scoria-rich flow is $1 \mathrm{~m}$ thick at $5,000 \mathrm{~m}$ a.s.1. and $1 \mathrm{~km}$ west of the crater where patches of ash and scattered scoria remain on Ubinas I. In the peat-bogs $9 \mathrm{~km}$ north of Ubinas (Vizcachani, Fig. 2), a similar gray, scoriaceous ash layer

winds. B and C Two measured road sections and two drilling sites in the lake show seven tephra-fall deposits from Ubinas, Misti, and Huaynaputina, which encompass the past ca. 15,000 years (Juvigné et al. 1997). The uppermost tephras are the andesitic ashfall layer LS2 from El Misti's 1400's event and the dacitic ashfall layer T.HP from the A.D. 1600 Huaynaputina Plinian eruption

overlies a few centimeters of peat on top of the whitish dacite ash from the 1600 A.D. eruption of Huaynaputina (Thouret et al. 2002). During the 20th century, six long fumarolic episodes and three ash emissions were linked to phreatic events, while the most recent, light ash fall occurred in 1969. Historical ash fall caused damage on cultivated areas and villages around Ubinas. Subsequent epidemics killed about 10 people and a great number of cattle (Rivera et al. 1998). On repeated occasions mudflows eroded cultivated terraces in the lowermost Rio Ubinas.

The most recent degassing and seismic episode occurred between December 1995 and the end of 1996 (Thouret et al. 1996). Fifty to 70 seismic events per day were recorded by the Instituto Geofísico del Perú for a few months after April 1996. The fumaroles consisted mainly of water vapour and $\mathrm{SO}_{2}$ and were expelled (at $440^{\circ} \mathrm{C}$ in July 1998 ) from six vents on the floor and in the walls of the crater. The fumaroles reached usually 100 to 
Fig. 9 Self-potential map superimposed on a topographic Digital Elevation Model of the Ubinas volcano

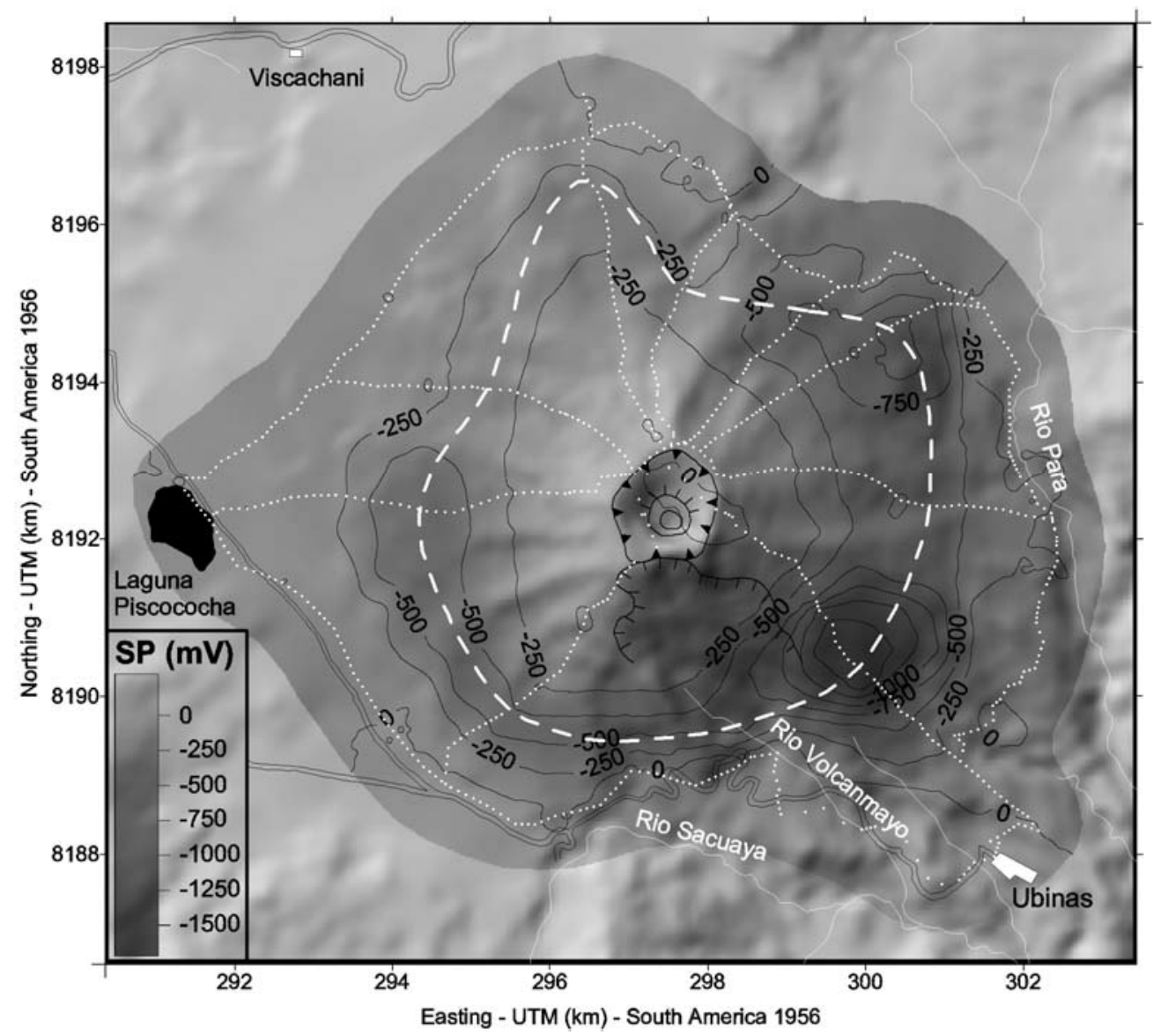

$600 \mathrm{~m}$ above the crater and steam clouds rose as much as $1.5 \mathrm{~km}$ above the caldera rim. The persistent fumaroles (since December 1995) are related to an active hydrothermal system (Finizola et al. 1998).

Tectonic features and volcano instability based on geophysical measurements

The self-potential (SP) method is frequently applied on active volcanoes to outline their hydrothermal system and structural control on fluid flow (e.g., Finizola et al. 2003). The SP method measures electric potential differences related to fluid circulation. Nine radial profiles from the summit to the base and also along a circular profile around the edifice have been measured (Fig. 9). Additional SP, ground temperature at $20 \mathrm{~cm}$ depth and $\mathrm{CO}_{2}$ soil concentration have been measured on the summit caldera floor.

The SP map of Ubinas volcano superimposed on a digital elevation model (Fig. 9) shows a SP minimum (as low as $1,700 \mathrm{mV}$ in magnitude) with a roughly circular shape $6 \mathrm{~km}$ in diameter. This SP minimum divides the edifice into (1) the lower half with a negative correlation between SP values and elevation, and (2) the upper half with a positive correlation. This pattern, common on active volcanoes, is thought to be the result of self potential produced by downward flow of vadose water on the lower flanks and upward flow of hydrothermal fluids on the upper flanks. Hence, the cone shows two distinct areas: hydrogeologic and hydrothermal (Fig. 9). On several volcanoes such as Stromboli (Finizola et al. 2002), the lateral extent of the hydrothermal system is constrained by permeable structural boundaries such as caldera walls. In the case of Ubinas, the stratigraphy sequence does not display large-volume ignimbrites that could account for a caldera $6 \mathrm{~km}$ across. The boundary between the hydrogeologic and hydrothermal systems is probably not linked to a volcano-structural limit. However, the boundary of the hydrothermal system is also elongated toward the NNW at the north base of the edifice. The elongated shape toward the NNW suggests that the hot body (magma or hot fluid rising system) follows a regional NNW trend (Thouret et al. 2001). Similar NNW-SSE fractures have been observed across the summit caldera wall and the SSE flank of the volcano, which may act as a path for fluid circulation. Interestingly, the rims of the scar inside the south flank of Ubinas, as well as the scars of the landslides which bound the depression of Rio Ubinas, are NNW-SSE trending, a fact which suggests some tectonic control on hydrothermal pathways and edifice instability (Figs. 2 and 10).

Our SP measurements as well as the persistent fumarolic and phreatic activity clearly indicate that Ubinas hosts a large and vigorous hydrothermal system that is 
Fig. 10 Compositional changes of Ubinas lavas with age. Note that eruptive ages are approximated for the different eruptive stages according to representative dated samples. The age axis is non-linear to account for the higher sampling density and higher compositional variability in the younger eruptive products
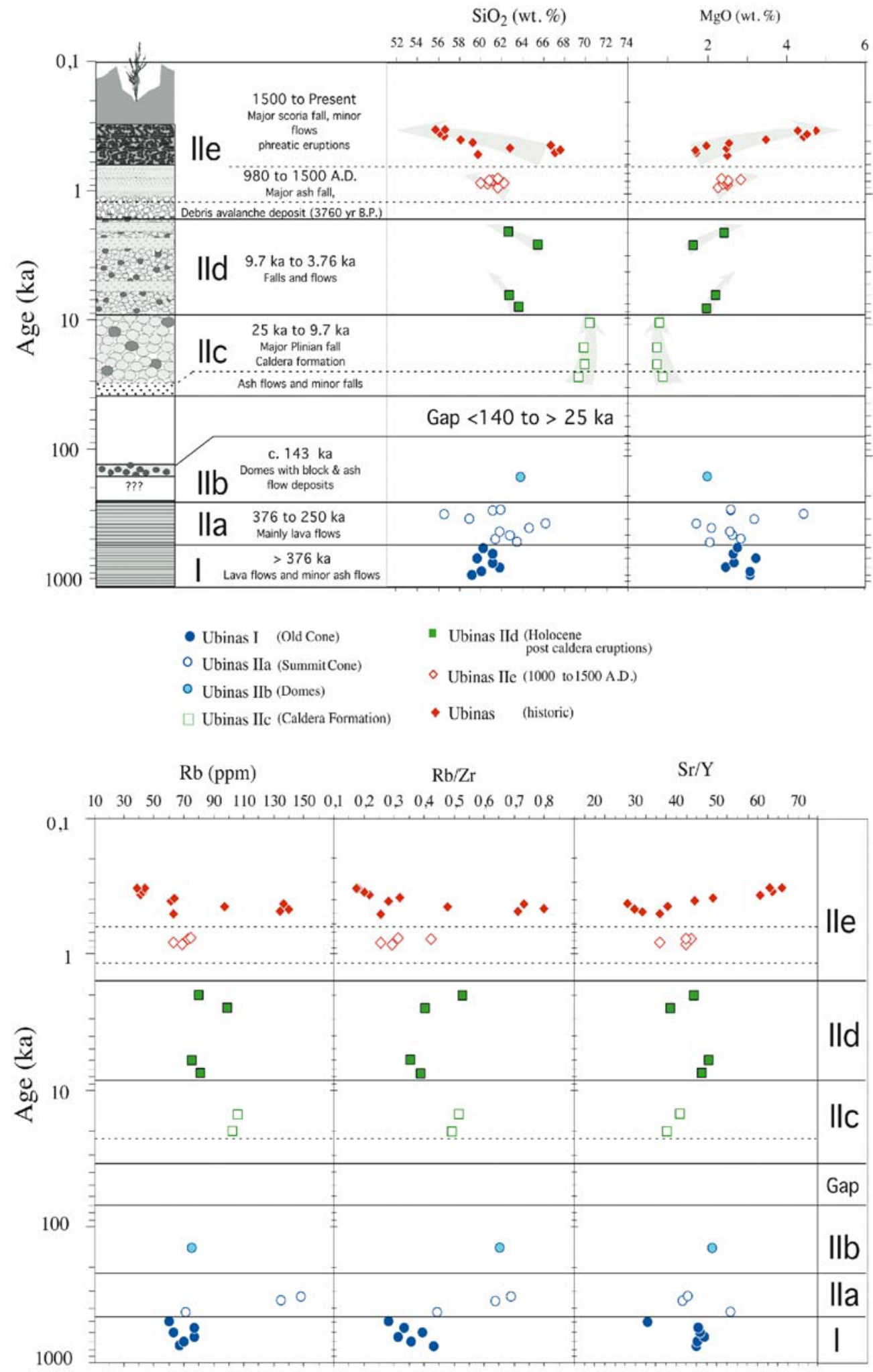
partly controlled by faults parallel to a regional structural pattern. Thus we argue that Ubinas should be considered a volcano that is highly gravitationally unstable.

\section{Petrography and geochemistry of lava flows and tephra}

\section{Petrography and mineralogy}

Forty-five rock samples collected at Ubinas mainly consist of andesites and dacites and rare basaltic andesites and rhyolites (Table 3, Data Rep. 4). Andesitic lavas are found throughout the entire volcanic history at Ubinas, except the major Plinian eruption episode (Ubinas IIc). The andesitic tephra also comprise Holocene and historical bombs, scoria, and Plinian pumice. Dacitic lavas essentially form the summit cone of Ubinas II, while the dacitic pumices belong to pyroclastic-flow deposits and to some Early-Middle Holocene and historical tephra-fall deposits. Basaltic andesites $\left(53-57 \mathrm{wt} \% \mathrm{SiO}_{2}\right.$ ) are found in historical ash-and-scoria flow deposits. Rhyolitic pumices are only found in Early Holocene pyroclastic deposits.

The mineral assemblages as well as the mineral compositions evolve in a way which is compatible with differentiation. Nevertheless, zoning patterns in phenocrysts indicate a more complex evolution (Data Rep. 4).

For example, plagioclases in the historical pyroclastic rocks frequently show reverse stepped-zoning with normally zoned cores usually bound by a sharp resorption surface and mantled by $50-\mu \mathrm{m}$ large inclusion-rich rims with higher An contents. High-amplitude compositional shift $(>10 \%)$ between cores and rims suggests that the phenocryst first nucleated in an evolved magma, and completed their growth in a more mafic magma. Large An-contrasts associated with resorption may be caused by inputs of more mafic magmas into the differentiating magma chamber rather than convection or boundary layer effects near the crystals, which would lead to low amplitude oscillatory changes (Ginibre et al. 2002; Allègre et al. 1981; Singer et al. 1995).

Olivines occur as phenocrysts and xenocrysts in Holocene pyroclastic rocks. Olivine xenocrysts in dacite (Ubi-39) show constant Fo contents $\left(\mathrm{Fo}_{77-80}\right)$, and reaction rims of small orthopyroxenes, oxide and plagioclase. Reaction rims indicate the chemical disequilibrium of olivine in the dacitic magma and may result of the incorporation as xenocrysts from a distinctly more mafic magma.

\section{Whole-rock geochemistry}

Samples were analysed by XRF, ICP-AES and ICPMS in laboratories at Göttingen University (Germany), Clermont-Ferrand, and Brest Universities (France). Duplicate analyses of selected samples were performed to check for consistency between the different laboratories. The concordance between labs was found to be within analytical errors for the XRF method and thus the combined data set is presented here. All major element analyses were recalculated to $100 \mathrm{wt} \%$ on a volatile-free basis (Table 3). Selected rocks have been analysed for LOI to confirm totals between 98 and $100 \%$. For the purpose of this study, we concentrate on the main processes operating in the magma chamber below Ubinas as well as the magma sources at depth. Special emphasis will be given to temporal variation of magma compositions with respect to the volcano evolution.

Ubinas rocks consist of high- $\mathrm{K}\left(2.1-3.91\right.$ wt $\left.\% \mathrm{~K}_{2} \mathrm{O}\right)$ calc-alkaline basaltic andesites, andesites, dacites, and rhyolites (55-71 wt\% $\mathrm{SiO}_{2}$, Fig. 11) and have trace element patterns with strong negative $\mathrm{Nb}$ and $\mathrm{Ta}$ anomalies typical for modern Andean subduction-related rocks (Fig. 12). Major elements such as $\mathrm{CaO}, \mathrm{MgO}, \mathrm{Al}_{2} \mathrm{O}_{3}$, $\mathrm{Fe}_{2} \mathrm{O}_{3}, \mathrm{TiO}_{2}$, show negative correlations with increasing differentiation $\left(\mathrm{SiO}_{2}\right)$. In contrast, the $\mathrm{K}_{2} \mathrm{O}$ contents increase with respect to $\mathrm{SiO}_{2} . \mathrm{Rb}, \mathrm{Th}, \mathrm{La}$, and $\mathrm{Nb}$ display incompatible behavior, whereas $\mathrm{Sc}, \mathrm{Sr}, \mathrm{Sm}, \mathrm{Ni}, \mathrm{V}, \mathrm{Cr}$, and Co are depleted during the differentiation. Thus major and trace elements are broadly consistent with differentiation by fractional crystallization of plagioclase, pyroxene and amphibole, with minor olivine.

Even though the overall major and trace elements suggest the range of compositions can be explained by simple differentiation by fractional crystallization, a closer inspection reveals complexities. For example, the rhyolitic pumice deposits (Ubi 48) of the large calderaforming eruption between $25 \mathrm{ka}$ and $14.7 \mathrm{ka}$, which represent the most evolved magma in terms of major element compositions, show the lowest to intermediate incompatible element contents (e.g., all REE, Fig. 12). Their REE patterns are not parallel to those of the more mafic rocks, being more depleted in HREE. Moreover, their $\mathrm{Sr}$ isotopic composition is more radiogenic and that of Nd less radiogenic (Table 3) than for all other rocks. Therefore, the most evolved magma is not a simple differentiation product of the intermediate andesites and dacites, and the influence of crustal melting and assimilation must be considered.

The trace element patterns of Ubinas rocks show that the suite is characterized by an increase in LILE $(\mathrm{K}, \mathrm{Rb}$, $\mathrm{Ba}, \mathrm{Th})$ and LREE with respect to HREE with increasing $\mathrm{SiO}_{2}$ (Fig. 12). REE and trace element patterns are broadly parallel, consistent with fractional crystallization. In detail, however, we find three distinct patterns and magma types: andesites of Ubinas I cone have a relatively flat REE pattern while the bulk of andesites and dacites for Ubinas II are very coherent with a slightly steeper pattern. The most evolved Plinian pumice has the lowest REE, steepest LREE/HREE, and a flat HREE pattern (Fig. 12). Only a few rocks have a small Eu anomaly indicating that plagioclase was not strongly fractionating Eu even in the most evolved rocks. Sr contents decrease with $\mathrm{MgO}$, however, the majority of compositions falls into a rather narrow range between 500 and $800 \mathrm{ppm}$. Only the most recent mafic andesites are distinct with ca. $1,100 \mathrm{ppm} \mathrm{Sr}$. 


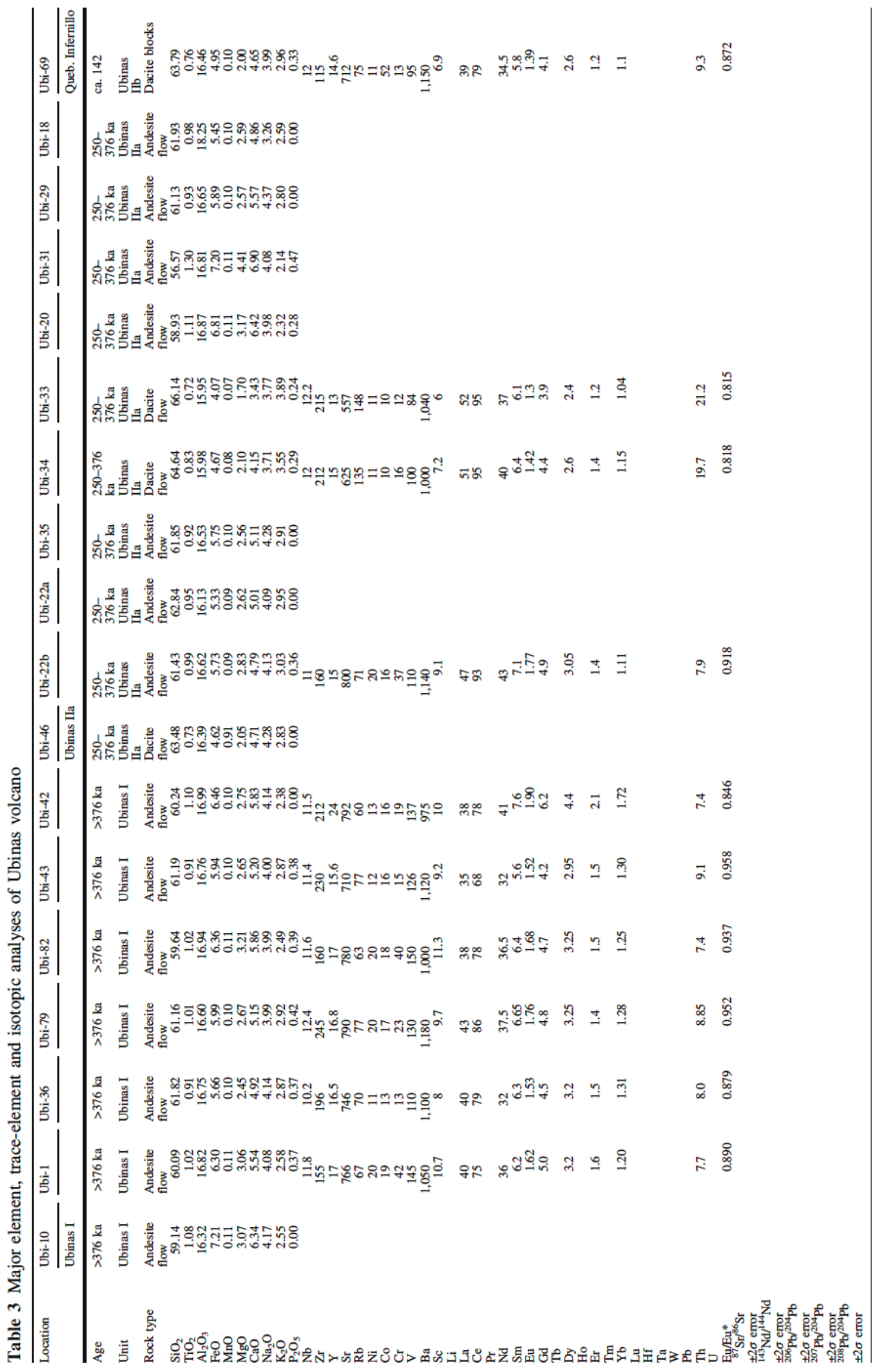




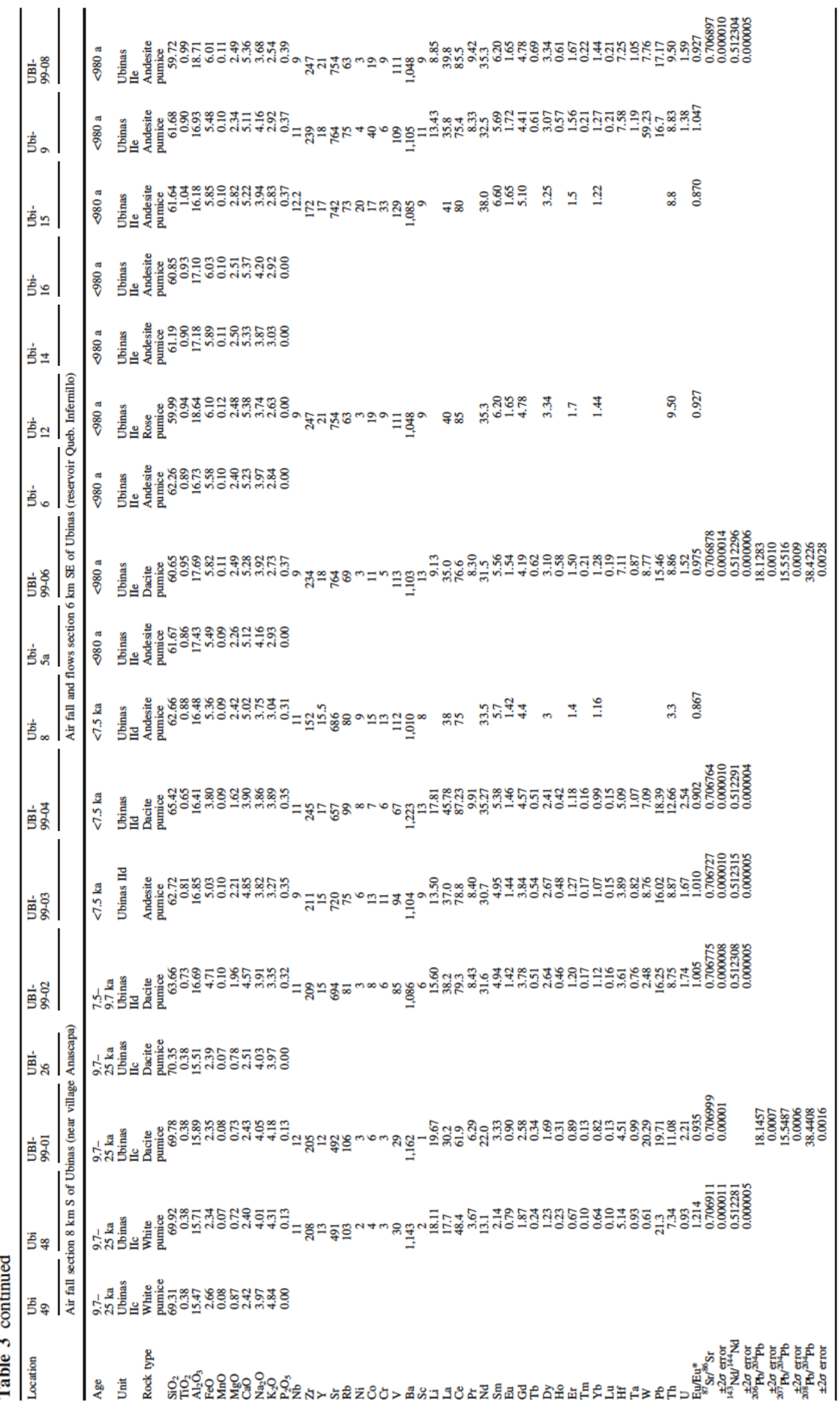




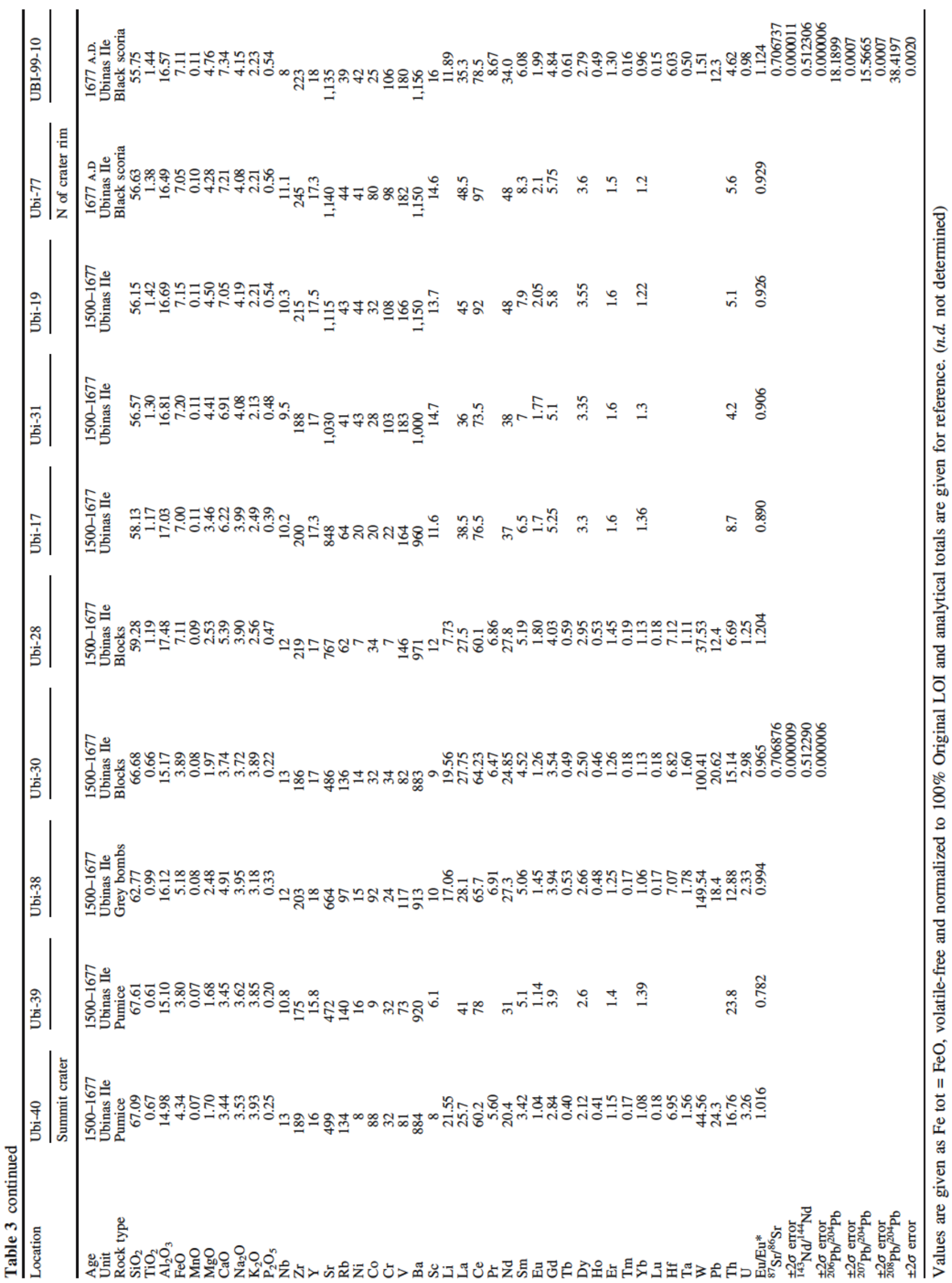


Fig. 11 Trace element patterns normalized to N-MORB (a) and REE-patterns normalized to $\mathrm{C} 1$ chondrites (b, c) (after Sun and McDonough 1989)
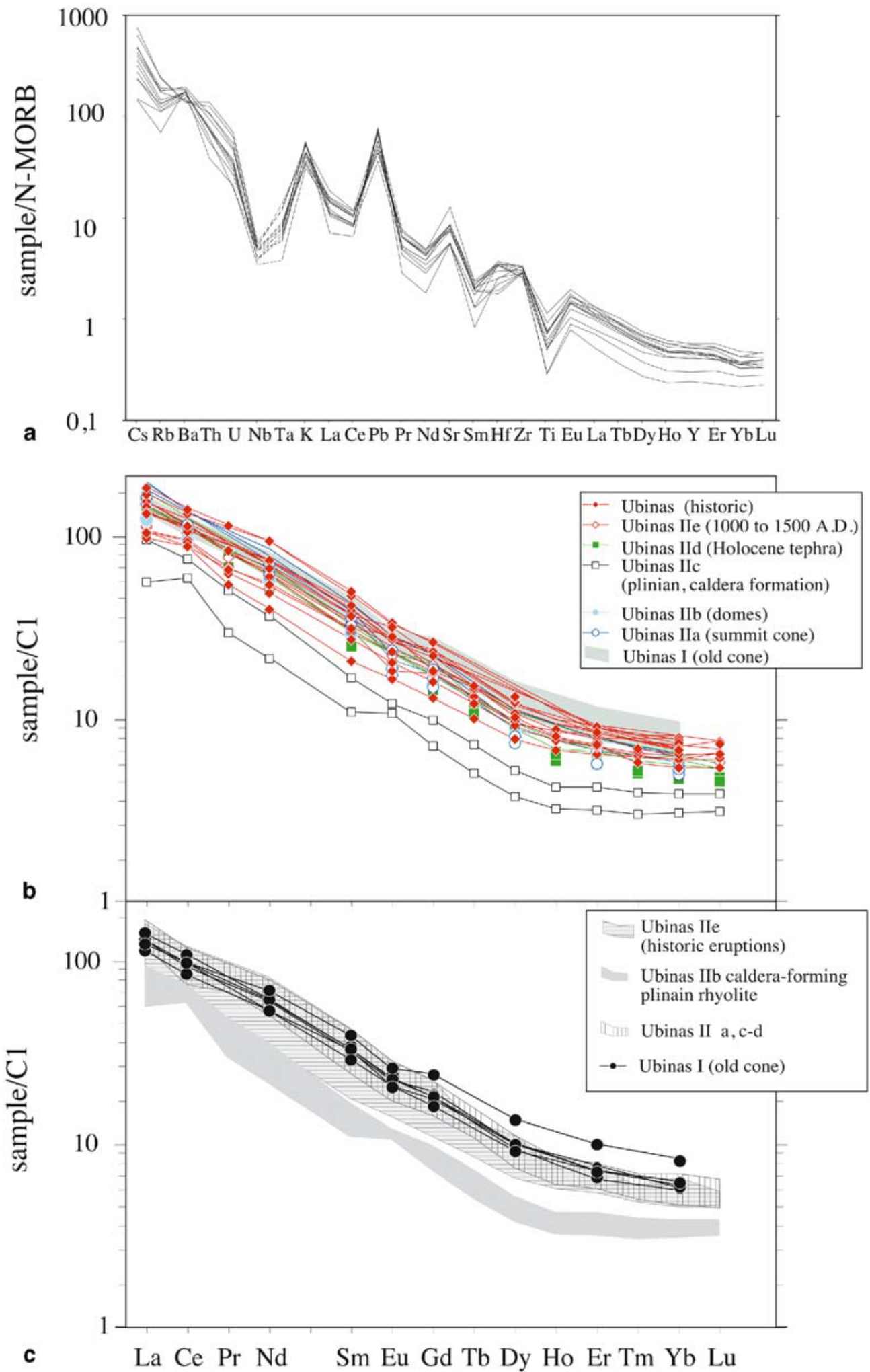

Variations of magma composition through time

Figure 11 plots selected oxides and trace element ratios against the stratigraphic sequence of the erupted products. As the sampling density and stratigraphic resolution is much higher for younger events, a logarithmic age axis was chosen. With this (intended) bias in mind, the following observations can be made:

Major element ranges, in particular for $\mathrm{MgO}$, tend to be higher in the younger historical and Holocene rocks of 
Fig. 12 Trace element systematics for Ubinas lavas and simple fractionation models; for discussion, see text

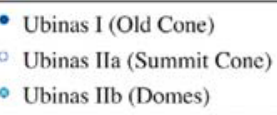

Ubinas I (Old Cone)

Ubinas IIa (Summit Cone)

Ubinas IIb (Domes)

- Ubinas IIe (1000 to 1500 A.D

Ubinas (historic)
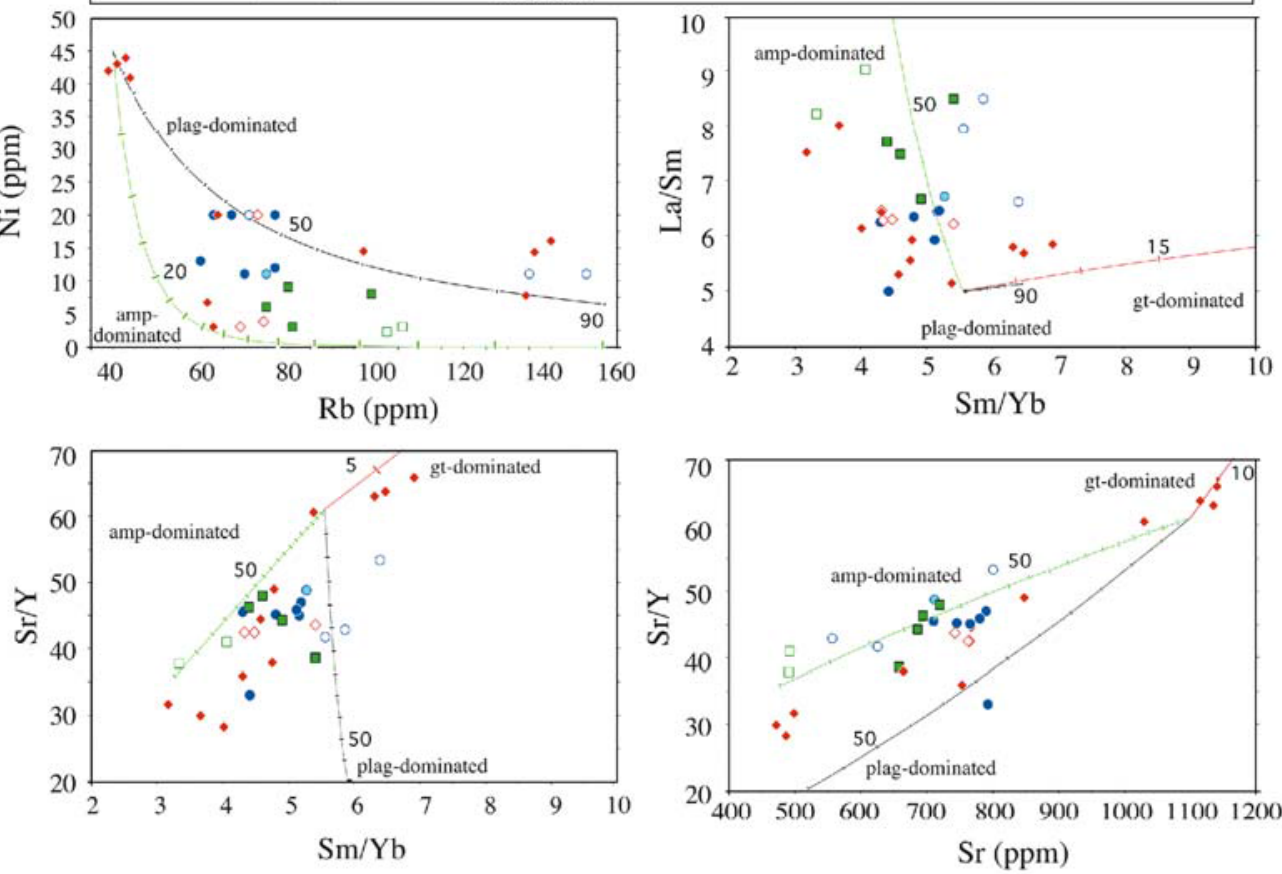

Fractionation models

- plagioclase-dominated fractionation amphibole-dominated fractionation garnet in residue

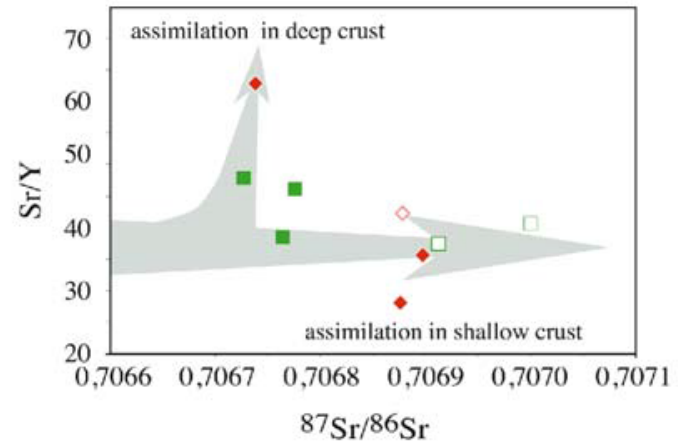
tic marks $=5 \%$ fractionation

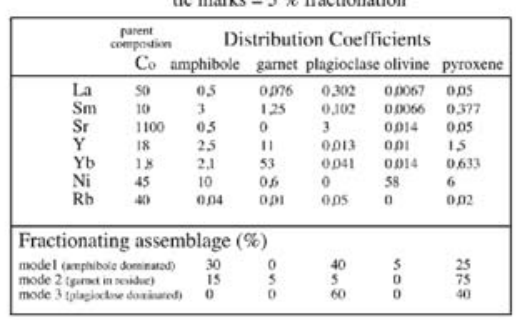

the summit caldera (IId-e) compared to the older rocks of summit cone (IIa) or in particular to the old cone Ubinas I. Even if older and more variable pyroclastic rocks may be underrepresented in the sampling of the older rocks (Ubinas I), we are confident that these trends are real and not a sampling artifact.

Stage I lavas are thus relatively homogeneous intermediate andesites followed by a more heterogeneous stage IIa which formed the present cone. The sequence of domes and their block-and-ash flow deposits (IIb) was not extensively analyzed because of its relatively monotonous petrographic composition. Following a period of quiescence between 140 and $25 \mathrm{ka}$, pumice deposits represent the most evolved magma erupted from Ubinas. Overall, there is an indication of successive cycles with an increased degree of differentiation (and assimilation) from stages I to IIc (Fig. 12). These cycles are also more compositionally variable with time. Incompatible trace element ratios (e.g., $\mathrm{Sr} / \mathrm{Y}, \mathrm{Rb} / \mathrm{Zr}$ ) have remained approximately constant within each stage but vary slightly between stages.

Holocene eruptions, in particular the historical events, produced unusually variable compositions with $\mathrm{MgO}$ ranging from 1.7 to $4.8 \mathrm{wt} \%$. At the same time, trace elements and trace element ratios also show a large range, $\mathrm{Sr} / \mathrm{Y}$ for example varies in historical eruptions from $<30$ to 65 . In these rocks, the absence of a correlation between the Eu anomaly and $\mathrm{Sr}$ indicates that simple plagioclase fractionation is not the reason for this change. 


\section{Discussion}

Evolution and magma sources

The overall compositional evolution of Ubinas magmas is mainly controlled by fractional differentiation. However, it has also been clear from the mineralogical observations, the trace element and isotopic variations that magma mixing, variable parental magmas, and assimilation also need to be considered.

It has long been accepted that the calc-alkaline magmas of the CVZ result from partial melting of the mantle wedge metasomatized by fluids derived from the dehydration of the subducted oceanic crust. The partial melting is often followed by crustal contamination during the differentiation (James 1982). Recent studies carried out on volcanoes of the CVZ, such as Ollagüe, Parinacota and Tata Sabaya (Davidson et al. 1990; Feeley and Hacker 1995; de Silva et al. 1993), have found magmas poor in HREE and $\mathrm{Y}$ but having high $\mathrm{Sr} / \mathrm{Y}$ ratios, similar to those of the Ubinas rocks (see also Mahlburg-Kay et al 1999). In all geochemical aspects, including radiogenic isotope ratios (Table 3), the spectra of trace elements of Ubinas fall into the same field as other typical CVZ rocks. Sr and $\mathrm{Nd}$ isotopes in the Ubinas rocks show high values of ${ }^{87} \mathrm{Sr} /{ }^{86} \mathrm{Sr}(0.706-0.707)$, and low values of $\varepsilon N d(-6.48)$. This and the depletion in Y and HREE in magmas from the CVZ is attributed to crustal assimilation in the presence of garnet at elevated pressures of the thickened continental crust (Davidson et al 1990; Mahlburg-Kay et al. 1999).

The majority of lavas and pyroclastic rocks of Ubinas seem to have evolved under relatively high water pressure. Evidence for high $\mathrm{P}_{\mathrm{H} 2 \mathrm{O}}$ includes the early occurrence of the opaque minerals, the ubiquitous presence of amphiboles, and the occurrence of clinopyroxene before plagioclase (Green 1972).

The most recent eruptive products show a large range in compositions (1.7 to $4.8 \mathrm{wt} \% \mathrm{MgO}$ ). Their variable trace element compositions (and ratios, see Fig. 12) do not support that the mafic members were parent to the evolved older rocks. The results of simple Rayleigh fractionation models with variable modes (amphiboledominated and plagioclase dominated) are compared to the effects of residual garnet during assimilation (Fig. 12). The large variations in trace element ratios such as $\mathrm{Sr} / \mathrm{Y}$ and $\mathrm{Sm} / \mathrm{Yb}$ and high $\mathrm{Rb}$ can only be explained if very large degrees of differentiation $(<90 \%)$ are assumed. This is clearly in conflict with major element evidence and the limited range in $\mathrm{MgO}$ between 1.5 and 5\%. Garnet is the only mineral that can control both $\mathrm{Sr} / \mathrm{Y}$ and $\mathrm{Sm} / \mathrm{Yb}$ and thus could explain the positive correlation between these ratios. Amphibole, by contrast, has little effect on $\mathrm{Sm} / \mathrm{Yb}$ but can, at least partly, explain the range in $\mathrm{La} / \mathrm{Sm}$ (Figs. 11 and 12) There is also an anti-correlation between ${ }^{87} \mathrm{Sr} /{ }^{86} \mathrm{Sr}$ and $\mathrm{Sr} / \mathrm{Y}$ with higher $\mathrm{Sr} / \mathrm{Y}$ and lower ${ }^{87} \mathrm{Sr} /{ }^{86} \mathrm{Sr}$ in the younger erupted products (Fig. 12). At the same time, we observe a temporal change from amphibole-bearing lavas to amphibole-free lavas. This suggests clearly that amphibole cannot be in control of higher $\mathrm{Sr} / \mathrm{Y}$ and that, with time, there is a tendency towards contamination of deeper, i.e., less radiogenic, garnet-bearing crust. Therefore, the trace element systematics suggest that Ubinas parent magmas had a variable "garnet" signature $(\mathrm{Sr} / \mathrm{Y}$ and $\mathrm{Sm} / \mathrm{Yb}$ that cannot be explained by amphibole or plagioclase fractionation alone). These magmas then evolved to different degrees of fractionation of amphibole and plagioclase-rich phenocryst assemblages.

We conclude from this that after a long time of steady evolution and similar magma injection into the magma chamber, the recent eruptions record a change in the feeding system with more mafic and more heterogeneous magmas from distinct sources.

Reversely zoned plagioclase phenocrysts in particular in the historical deposits show wavy dissolution surfaces between core and rim and melt inclusions entrapment in the rim which suggest that the crystals underwent a resorption episode in response to physical and/or chemical changes in the magma reservoir. The associated major compositional jump ( $>10 \%$ An) indicates that this dissolution event is related to more mafic magma recharge and subsequent magma mixing (Singer et al. 1995; Ginibre et al. 2002). Experimental studies performed to reproduce such complex reverse zoning within plagioclase phenocrysts demonstrate that temperature and chemical compositions are the determinant parameters to form these disequilibrium textures (Nakamura and Shimakita 1998). Consequently, reversely zoned plagioclases are records of mafic magma inputs into the differentiating magma chamber of Ubinas and that it has been regularly recharged with new magma. The mixing process may have triggered violent eruptions, especially after $25 \mathrm{ky}$ ago when the range in magma compositions was particularly large and the chamber periodically and partially emptied during eruptions. The change from rather quiet effusions of mostly andesite magmas (Ubinas I and IIa) to more violent Plinian eruptions with a large compositional spectrum of products suggests that the magma system below Ubinas was significantly modified with higher recharge rates beginning at ca. 25-14.7 ky ago.

Taken together, these observations indicate that the magmatic plumbing system below Ubinas has changed from a more steady state before the large-scale calderaforming eruptions about 25-9.7 ka ago to an unsteady system with increased (?) injections since then. The mafic melts feeding the chamber and their large variability in their degree of differentiation suggests the existence of small and distinct magma batches. Abundant evidence for disequilibrium in the phenocryst assemblage for younger rocks also suggests increased rates of magma mixing at this later stage, which were enhanced by increasingly deeper assimilation. Similar abrupt changes have been observed in other Central Andean volcanoes (e.g., Parinacota volcano in Northern Chile, Wörner et al. 1988; Bourdon et al 2000) and may be of general importance in the evolution of large arc magma systems on thick continental crust. However, what exactly controls these changes is still poorly understood. Changes in stress re- 
gime of the volcano due to erosion and, more likely, catastrophic gravitational unloading may play a major role.

For the future, a replenished magma chamber may evolve again towards a steady state. Until then we can expect a continuation of small volume eruptions of diverse compositions. These may include small Plinian pumice eruptions as well as vulcanian scoria deposits. At present, there is no indication of a system maturing towards a large catastrophic Plinian explosion.

Volume versus time relationships at Ubinas

Ubinas volcano results from the growth and denudation of two edifices, Ubinas I and Ubinas II, from the Middle Pleistocene to Present times (Figs. 4-8, Tables 1 and 2). Ubinas II consists of five periods $<376 \mathrm{ky}$. The preserved volume of the Ubinas II composite cone is approximately $56 \mathrm{~km}^{3}$ and the growth period (preceding the stratigraphic gap and the summit caldera- forming period) is estimated to be approximately $234 \mathrm{ky}$. Hence the eruption rate ranges between 0.17 and $0.22 \mathrm{~km}^{3} / \mathrm{ky}$, i.e., three time less than the estimated rate at the younger and more voluminous Misti volcano (Thouret et al. 2001), but similar to the average eruption rate of the Tongariro composite cone of comparable size and activity (New Zealand, Davidson and de Silva 2000). However, the Ubinas edifice has collapsed twice towards the south: Ubinas I between ca. 376 and 250 ky (i.e., the age of the largest dome that grew inside the scar of the flank failure), and Ubinas II during the 140-25 ky stratigraphic gap. The collapse of the south flank is a continuing process, as the most recent debris avalanche is not much older than $3.6 \mathrm{ky}$. In addition, the preserved volume of lava and tephra does not account for glacial erosion during the stratigraphic gap.

Following a stratigraphic gap and the flank collapse which has unloaded the magma system below, the destruction by explosion of the summit cone (between 25 and $9.7 \mathrm{ky}$ ) may have lowered the volcano by up to $400 \mathrm{~m}$, based on a reconstructed profile of the lava flows. Consequently, a rapid change in magmatic regime has been observed to one with high magma input, high mixing and eruption rates, as shown in the products of several $\mathrm{km}^{3}$ of the sustained large-scale (VEI $>4$ ) Plinian explosive eruptions since ca. $25-14.7 \mathrm{ky}$.

\section{Hazard assessment based on eruption history and on scenarios}

Ubinas has been the most active volcano in southern Peru since A.D. 1550 although its eruptive activity has been moderate and restricted to ash fall, small mudflows due to snow melting, and degassing episodes, with the exception of the VEI 3 eruption in A.D. 1677. However, thick Plinian fall deposits and phreatomagmatic ejecta, dispersed as far as $35 \mathrm{~km}$ from the edifice, point to six largescale eruptions (two of them with VEI > 4) and to the formation of a summit caldera between 25 and $9.7 \mathrm{ka}$. The most recent Plinian eruption A.D. 1000-1160 emplaced more than $1 \mathrm{~km}^{3}$ of pumice. Debris-avalanche deposits witness the south flank failures and subsequent avalanches before and during the Middle Holocene. A thick succession of block-and-ash flow deposits older than the Holocene points to the repeated growth and destruction of several domes on the south flank.

The hazard-zone map (Fig. 13) shows five areas likely to be affected by several processes, which would occur during three types of eruption scenarios, based on the available stratigraphy and chronology. These processes are ranked according to their frequency during the past 25,000 years.

- Ash fall (and phreatic and phreatomagmatic ejecta) can mantle an area of at least $6 \mathrm{~km}$ around the summit; pumice fall can mantle an area several tens of kilometers around the summit, especially towards the south-southeast and the west-southwest owing to prevailing winds (NCEP-NCAR, 1998; Fig. 8a).

- Lahars can sweep the Rio Ubinas valley and its tributaries as far as $15 \mathrm{~km}$ owing to a low height $(3.7 \mathrm{~km}) /$ length $(13.5 \mathrm{~km})$ ratio of 0.207 from the summit $(5,600 \mathrm{~m}$ a.s.1.) to the confluence of the Rio Tambo canyon downvalley at $1,900 \mathrm{~m}$ (Figs. 2 and 13).

- Flank failure leading to debris avalanches may occur on the steep-sided, fractured, and hydrothermally altered south flank of the edifice (Fig. 3a).

- In case of sub-Plinian or Plinian eruptions, pyroclastic flows can spill over the caldera rim and flow to all directions to the west, the northwest, the east, and the south. If domes fill the small summit caldera, blockand-ash flow deposits can also spill over the caldera walls and flow down the flanks to be channeled in the radial drainage to a distance of at least $8 \mathrm{~km}$.

- Lava flows can fill the valleys on all flanks of the summit cone, after the summit depression has been filled, but will not commonly exceed distances of $5 \mathrm{~km}$ from the summit due to their high viscosity.

- Lava flows and pyroclastic flows may spill over the northern wall which is the lowest part of the summit caldera rim. More hazardous pyroclastic flows may also spill over the southern rim wall, the most hydrothermally altered and unstable part of the caldera.

According to the recent eruptive behavior, three eruptive scenarios may occur at Ubinas. The most probable scenario consists of small phreatic or phreatomagmatic events, moderate ash-fallout, and small lahars (e.g., similar to the 1906, 1951, and 1969 events, and to the 1990 1998 eruptive episode at Nevado Sabancaya; Gerbe and Thouret 2004), on a 33 to 100-year interval. The second probable scenario would include scoria-fall and flowforming eruptions such as the A.D. 1677 event which may recur every 500 years on average. The third scenario is a sub-Plinian eruption with avalanches off the south flank and lahars. The recurrence time is $2,000-4,000$ years. The worst-case scenario would be a Plinian eruption with 
Fig. 13 Hazard map showing areas likely to be affected by pyroclastic flows and surges, lahars, debris avalanches, and lava flows from Ubinas volcano. The $50-\mathrm{cm}$ isopach of a potential Plinian tephra fall, based on the voluminous pumice-fall deposits of Holocene age, is shown in Fig. 8a (stippled area). A $10+\mathrm{cm}$-thick Plinian ashfall from Ubinas would mantle a wide area towards the west as shown in Fig. 8a, due to prevailing eastern winds. This was the case for the A.D. 1600 Huaynaputina eruption (Thouret et al. 2002)

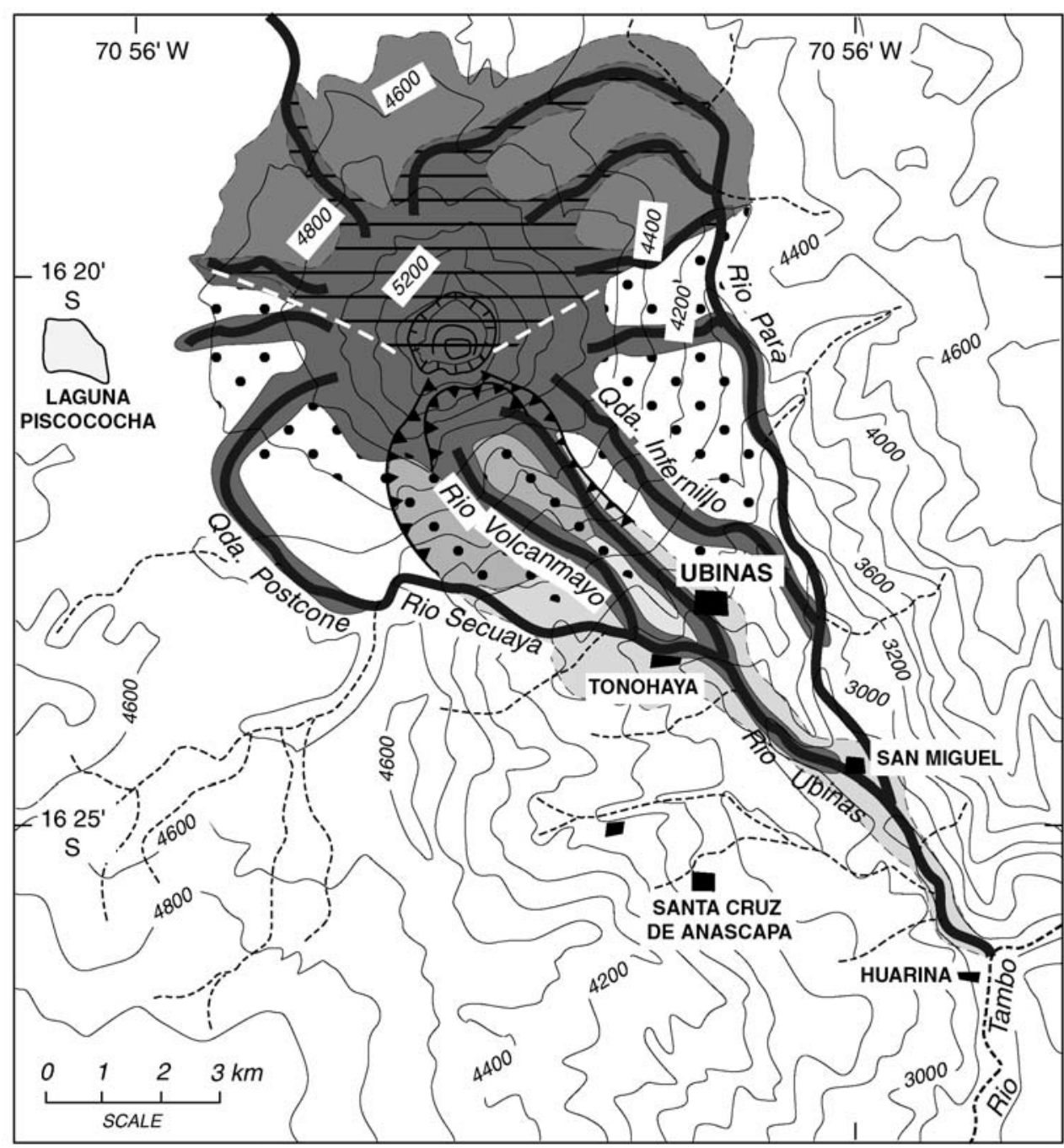

$\because \quad$ Valleys potentially affected by channeled pyroclastic flows and slopes potentially affected by pyroclastic surges (dots)

$\cup$ Northwest, North, and Northest flanks of the volcano most likely to be affected by pumice or scoria flows (based on historical scoria-flow deposits)

Valleys likely to be affected by lahars (volcanic debris flows)

Areas potentially affected by debris avalanches from a failure of the south flank Two magnitudes are based on: a) debris-avalanche deposit of Holocene age

b) debris-avalanche deposit of middle Pleistocene age

Areas potentially affected by lava flows, based on the extent of late Pleistocene lavas that formed the summit cone and lava domes large volumes of pumice falls and flows, lahars, and debris avalanches. Events of that size have occurred at least two times over the past ca. $25 \mathrm{ky}$. At present, the probability of the last scenario is fairly low.

\section{Conclusions}

Our study of Ubinas volcano has identified it to be the most active volcano is southern Peru in historical times. The detailed stratigraphic record and the new chronological data coupled with geophysical, mineralogical, geochemical, and isotopic data allow to link the volcano evolution to its present hazard. This is done by tracing the volcano history with respect to growth and gravitational destruction, changing parental magma sources and recharge frequencies, and its present hydrothermal system.

Ubinas had two main periods of growth and two periods of destruction. Ubinas I was built by relatively monotonous andesite lavas prior to $376 \mathrm{ky}$ ago. Ubinas I collapsed and a subsequent debris-avalanche deposit $\left(2.8 \mathrm{~km}^{3}\right)$ was emplaced in the Rio Ubinas valley. Ubinas II comprises andesitic to dacitic lava flows (376 to $142 \mathrm{ky}$ ) that built the summit cone. A large andesitic 
dome was emplaced ca. $250 \mathrm{ky}$ on the south flank accompanied by voluminous block-and-ash flows reaching as far as $7 \mathrm{~km}$ to the south of the summit. At the end of Ubinas II, a summit caldera formed between 25-9.7 ky, linked to large-scale Plinian eruptions. Failure of the south flank produced a debris-avalanche deposit that is not much older than $3.6 \mathrm{ky}$. The last Plinian eruption occurred ca. A.D. 1000-1160. Since then and to the present day, Ubinas is in persistent, fumarolic and phreatic activity.

Chemical characteristics of the Ubinas magmas mainly result from fractional crystallization and assimilation at various crustal levels. Magma mixing is obvious from the mineralogical and geochemical record and, in combination with shallow aquifers of the hydrothermal system, may have contributed to the triggering of the eruptions. Distinctive trace element and isotopic characteristics reflect different parent magmas that recharged the magma chamber. Ubinas I and early Ubinas II lavas are relatively similar in composition. However, towards the present, there is a trend towards increased rates of mixing and differentiation, deeper contamination and smaller individual magma volumes of single eruptive events. This change is observed since the large-scale caldera-forming eruptions that occurred after $25 \mathrm{ka}$ ago. Therefore, Ubinas is presently in the process of changing its magmatic regime towards a higher recharge rate.

Surface geology and geophysical (self-potential and seismicity) measurements indicate that Ubinas volcano hosts a large over-pressurized hydrothermal system. The large-scale fluid circulation and related hydrothermal system inside the volcanic edifice are strongly influenced by regional NNW-SSE tectonic trends. These faults intersect the scar of the south flank sector collapse, increasing the weakening of the edifice towards the south. This situation has resulted in repeated gravitational failure of the unstable southern flank. Subsequent emplacement of debris-avalanche deposits is known to have occurred at least twice and as recently as the Middle Holocene. In addition, the over-pressurized hydrothermal system and the location of the crater close to the hydrothermally altered south flank may increase the hazard in case of magma-water interaction. Additional seismic activity, common in the Arequipa area, can trigger also rockslide avalanches off the unstable south flank without any eruption.

Ubinas therefore is not only the most active volcano in southern Peru. The changing magmatic regime coupled with the strong hydrothermal system and the oversteepened unstable southern flank suggest that it may also potentially be the most hazardous volcano in the area where 5,000 people live within a $15 \mathrm{~km}$ radius. In addition, strong Plinian eruptions as recorded from the recent past may result in ashfall that can be transported to the area of the city of Arequipa and Chiguata where $1,000,000$ people live.

Acknowledgments This work has been carried out through a cooperation agreement between IRD Institut Français de Recherche pour le Développement and IGP Instituto Geofísico del Perú. We thank O. Macedo, J. Dávila, D. Ramos, R. Pinto and J. C. Gómez, N. Fournier, V. Glock and F. Sortino for their help in the field. The research program has been supported by IRD and the Laboratoire Magmas et Volcans, Université Blaise-Pascal and CNRS in Clermont-Ferrand (France) where M. Rivera carried out a Master Sc. project (1999-2000). G. Hartman and K. Simon (both GZG) are thanked for isotope and ICPMS trace element analyses, respectively. This cooperation was supported financially by a DAADPROCOPE programme to JCT and GW as well as by DFG Leibniz award. Géosciences Azur contribution no. 567. Valuable comments provided by Dr. T. Spell, Dr. C. Siebe, and Dr. E. Smith, are greatly acknowledged.

\section{List of data repository}

\section{Data Repository 1}

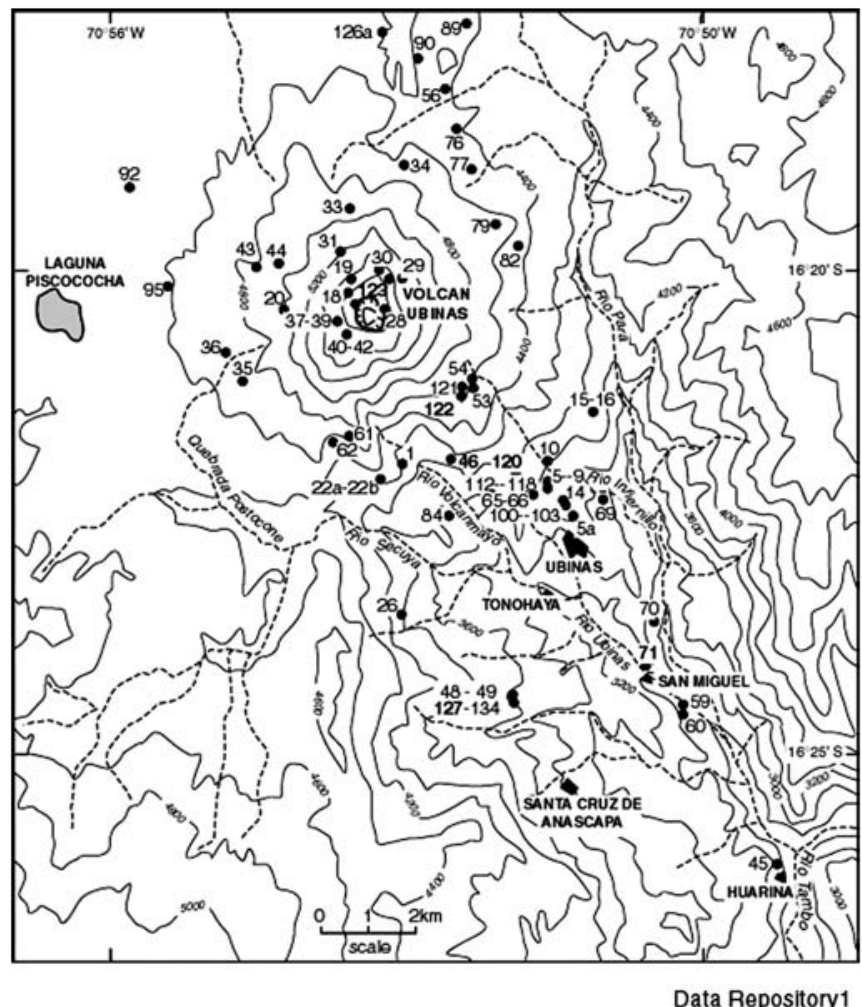

Sketch map of the Ubinas volcano and surroundings showing the location of the analysed lavas and tephra. In addition, dated ${ }^{40} \mathrm{Ar} /{ }^{39} \mathrm{Ar}$ lavas (bold numbers) and tephra-fall deposits $\left({ }^{14} \mathrm{C}\right)$ are shown, as well as the sites of the drilled peat cores (see Fig. 2).

Data Repository 2:

sample preparation and ${ }^{40} \mathrm{Ar} /{ }^{39} \mathrm{Ar}$ dating method

Four biotite (samples Ubi 46, Ubi 71, Ubi 120, and Ubi 127) and two amphibole (samples Ubi 122 and Ubi 123) concentrates and a whole rock (Ubi 122) were used (see Fig. 2 for location). In order to separate the mineral concentrates, the rocks were crushed and sieved through the $800-500$ and $500-300 \mu \mathrm{m}$. The minerals were con- 
centrated using bromoform and eventually selected under binocular microscope. The mineral concentrates were wrapped in copper-foil packets (furnace experiment) and in aluminum-foil (laser experiment) and irradiated in the $5 \mathrm{C}$ position at the nuclear reactor of McMaster University (Hamilton, Canada). Irradiation lasted for one hour with cadmium shielding except for the biotites of the sample Ubi 127, which were irradiated two hours. The samples were associated with the Fish Canyon sanidine (FCS) as a neutron flux monitor of the reactor (J-value determination) assuming a FCS age of 28.02 Ma (Renne et al. 1998). A whole-rock thin slab of $205 \mathrm{mg}$ was also cut from the sample Ubi 122 and irradiated for two hours.

Age determination was performed in the Laboratory of Geochronology of UMR Géosciences Azur in the university of Nice, France. Step heating of individual grains of biotite were carried out using a 50-W Synrad $\mathrm{CO}_{2}$ laser. Each step lasted $5 \mathrm{~min}$, including $1 \mathrm{~min}$ for heating and $4 \mathrm{~min}$ for cleanup of the released gas, before introducing the gas in the spectrometer. Isotopes were measured statically with a VG3600 mass spectrometer working with a Daly detector system. The gas extractions for bulk samples (amphiboles and biotites) and whole rock were performed in double-vacuum, high frequency heated furnace, connected to a stainless steel purification line and analyzed with a mass spectrometer composed of a $120^{\circ}$ M.A.S.S.E tube, a Bauer-Signer GS98 source, and a Balzers electron multiplier.

Ages were calculated from measured isotope ratios corrected for mass discrimination, system blanks, and interfering isotopes produced during irradiation. For the laser experiment, blanks routinely measured every three steps, were in the range $40-90,2-10,2-6 \times 10^{-14}$ ccSTP for the masses 40,39 , and 36, respectively. The argon isotopes were on the order of up to $2000,5-100,2-100$ times the blank levels, respectively, in part related to the weight of the analyzed mineral.

During the furnace experiments, heating lasted $20 \mathrm{~min}$ for each temperature step followed by $5 \mathrm{~min}$ for cleanup of the released gas, before introducing the gas in the spectrometer. Argon isotopes were of the order of 100 $2,000,100-1,000$ and $2-200$ times the blank levels for the masses $40,39,36$, respectively. In some high temperature steps, measured ${ }^{36} \mathrm{Ar}$ was near the blank level. Mass discrimination was monitored by regularly analyzing air pipette volume and averaged $1.00721 \pm 0.19 \%$ over a 2 year period for the laser system and was ranging from 1.00740 to $1.00606( \pm 0.15 \%)$ for the HF furnace system.

The criteria used for a plateau age are: (1) the plateau should contain at least $70 \%$ of ${ }^{39} \mathrm{Ar},(2)$ the plateau should include at least three following steps of temperature, and (3) the integrated age of the plateau should concur within $2 \sigma$ with each apparent age of the plateau.

For each biotite sample, single grains were fused with laser to check the possibility of heterogeneity of the sample. Each single grain of biotite was first moderately heated (one or two steps) before fusion in order to release part of the atmospheric contamination. The aim of this procedure was to reduce the atmospheric contamination before the fusion step. However, this procedure was not very efficient and in most of the sample, all the steps include high level of atmospheric contamination. Generally, we retained the age of the fusion step, as it includes an important part of the total ${ }^{39} \mathrm{Ar}$ released but when the sample released ${ }^{39} \mathrm{Ar}$ in the lower temperature steps, we calculated a plateau age. Integrated (total gas) ages appear in the data table but were not used for the discussion.

\section{Data Repository 3: ${ }^{40} \mathrm{Ar} /{ }^{39} \mathrm{Ar}$ analytical data}

Laser experiments: high-temperature (fusion) step ages are generally preferred but some plateau age are also used (see text for explanation).

${ }^{39} \mathrm{Ar}(\%)=$ fraction of ${ }^{39} \mathrm{Ar}$ released for each step; ${ }^{37} \mathrm{ArCa}{ }^{39} \mathrm{ArK}=\mathrm{Ar}$ isotopes produced by $\mathrm{Ca}$ and $\mathrm{K}$ neutron interferences; ${ }^{40} \mathrm{Ar} *=$ radiogenic ${ }^{40} \mathrm{Ar}$. The error bar is at the 1s level and does not include the error of the $\mathrm{J}$ irradiation parameter (estimated at $0.2 \%$ ). Corrections factor for the interfering isotopes produced by nuclear reactions on potassium and calcium in the McMaster reactor were $\left({ }^{39} \mathrm{Ar} /{ }^{37} \mathrm{Ar}\right) \mathrm{Ca}=7.06 \times 10^{-4}$, $( \pm 4 \%), \quad\left({ }^{36} \mathrm{Ar} /{ }^{37} \mathrm{Ar}\right) \mathrm{Ca}=2.79 \times 10^{-4} \quad( \pm 3 \%) \quad$ and $\left({ }^{40} \mathrm{Ar} /{ }^{39} \mathrm{Ar}\right) \mathrm{K}=1 \times 10^{-3}( \pm 4 \%)$. Isotopic ratio were

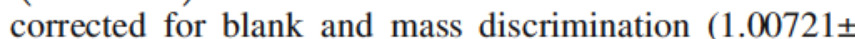
$0.19 \%$ for the laser system and 1.00740 to 1.00606 $( \pm 0.15 \%)$ for the HF furnace system. Ages were calculated using the decay constants proposed by Steiger and Jaeger (1977).

Representative electron microprobe analyses of phenocrysts in the Ubinas rocks. $\mathrm{Fe}_{2} \mathrm{O}_{3}$ * calculated after Papike et al. (1974) and Tindle and Webb (1994); Endmember components of "quadrilateral" pyroxenes ( $\mathrm{mol} \%)$ normalized to atomic $\mathrm{Ca}+\mathrm{Mg}+\Sigma \mathrm{Fe}=100$ with $\Sigma \mathrm{Fe}=$ $\mathrm{Fe}^{2+}+\mathrm{Fe}^{3+}+\mathrm{Mn}$ (Morimoto et al. 1988); Mg-no. = $100 \mathrm{Mg} /(\mathrm{Mg}+\mathrm{Fe})$, atomic; $m g h t$ magnesio-hastingsite; $c$ phenocryst core; $r$ phenocryst rim. 


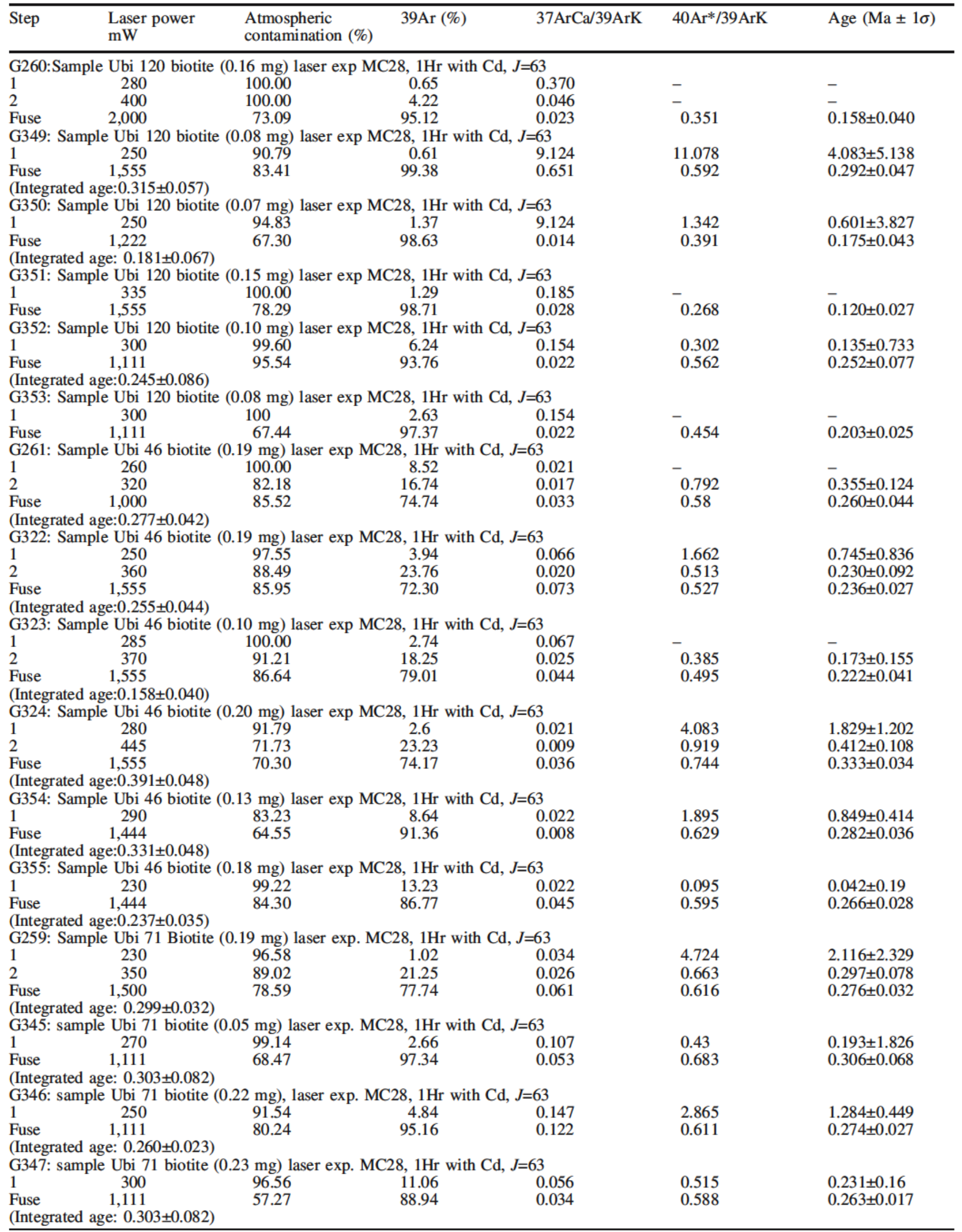




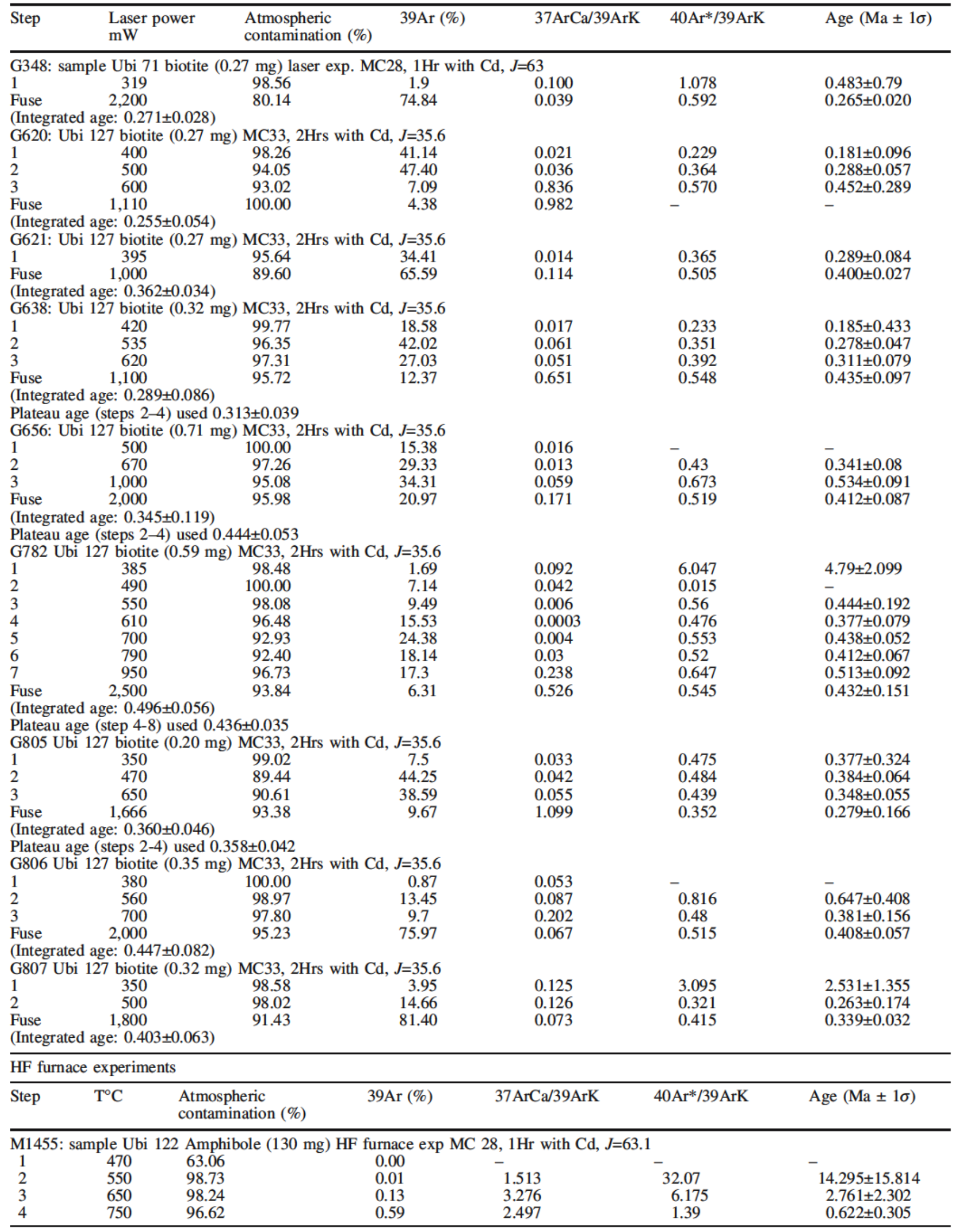


HF furnace experiments

\begin{tabular}{|c|c|c|c|c|c|c|}
\hline Step & $\mathrm{T}^{\circ} \mathrm{C}$ & $\begin{array}{l}\text { Atmospheric } \\
\text { contamination }(\%)\end{array}$ & $39 \operatorname{Ar}(\%)$ & 37ArCa/39ArK & 40Ar*/39ArK & Age $(\mathrm{Ma} \pm 1 \sigma)$ \\
\hline 5 & 850 & 96.48 & 1.12 & 1.253 & 0.658 & $0.295 \pm 0.155$ \\
\hline 6 & 950 & 96.53 & 1.6 & 0.802 & 0.578 & $0.259 \pm 0.132$ \\
\hline 8 & 1,100 & 97.46 & 11.47 & 5.857 & 0.554 & $0.248 \pm 0.076$ \\
\hline 9 & 1,150 & 89.90 & 30.93 & 6.572 & 0.819 & $0.366 \pm 0.029$ \\
\hline 10 & 1,160 & 86.30 & 15.93 & 6.675 & 0.749 & $0.335 \pm 0.025$ \\
\hline 13 & 1,250 & 83.92 & 7.82 & 6.918 & 1.069 & $0.479 \pm 0.039$ \\
\hline 14 & 1,300 & 99.01 & 0.86 & 7.513 & 0.078 & $0.035 \pm 0.297$ \\
\hline 15 & 1,350 & 100.00 & 0.21 & 7.28 & - & - \\
\hline Fuse & 1,450 & 100.00 & 0.06 & 7.817 & 0.01 & $0.005 \pm 2.311$ \\
\hline \multicolumn{7}{|c|}{ (Integrated age: $0.342 \pm 0.018$ ) } \\
\hline \multicolumn{7}{|c|}{ M1456 sample Ubi 123 Amphibole (282 mg) HF furnace exp MC $28,1 \mathrm{Hr}$ with Cd, $J=63.1$} \\
\hline 1 & 550 & 100.00 & 0.00 & 0.001 & - & - \\
\hline 6 & 1,050 & 87.77 & 6.81 & 3.669 & 3.002 & $1.343 \pm 0.105$ \\
\hline 7 & 1,100 & 88.01 & 37.02 & 5.559 & 1.242 & $0.556 \pm 0.047$ \\
\hline 8 & 1,150 & 76.26 & 11.78 & 5.784 & 0.844 & $0.378 \pm 0.019$ \\
\hline 9 & 1,180 & 78.92 & 13.46 & 5.847 & 0.886 & $0.396 \pm 0.020$ \\
\hline 10 & 1,220 & 92.41 & 10.43 & 6.026 & 0.999 & $0.447 \pm 0.064$ \\
\hline 11 & 1,260 & 73.47 & 13.86 & 6.374 & 1.419 & $0.635 \pm 0.025$ \\
\hline 12 & 1,300 & 42.06 & 0.22 & 14.748 & 13.068 & $5.839 \pm 0.404$ \\
\hline 13 & 1,350 & 82.91 & 0.08 & 28.973 & 4.188 & $1.873 \pm 0.958$ \\
\hline Fuse & 1,450 & 100.00 & 0.02 & 18.109 & - & - \\
\hline \multicolumn{7}{|c|}{ (Integrated age: $0.658 \pm 0.024$ ) } \\
\hline \multicolumn{7}{|c|}{ M1622: Ubi 122 whole rock, (205 mg) MC 33, 2Hrs with Cd, $J=34.60$} \\
\hline 1 & 400 & 67.37 & 0.00 & 0.021 & 151.609 & $119.68 \pm 204.6$ \\
\hline 2 & 450 & 100.00 & 0.00 & 0.020 & - & - \\
\hline 12 & 1,050 & 94.68 & 8.79 & 0.715 & 0.123 & $0.101 \pm 0.013$ \\
\hline 13 & 1,180 & 96.39 & 8.03 & 1.300 & 0.382 & $0.312 \pm 0.056$ \\
\hline 14 & 1,300 & 93.36 & 8.63 & 1.801 & 0.722 & $0.589 \pm 0.086$ \\
\hline 15 & 1,500 & 92.07 & 0.90 & 3.219 & 0.954 & $0.779 \pm 0.188$ \\
\hline Fuse & 1,550 & 100.00 & 0.06 & 3.208 & - & - \\
\hline \multicolumn{7}{|c|}{ (Integrated age: $0.180 \pm 0.009$ ) } \\
\hline \multicolumn{7}{|c|}{ Mini plateau age (steps $7-10$ ) used $0.142 \pm 0.003$} \\
\hline \multicolumn{7}{|c|}{ M1448, sample Ubi 46 Biotite $(170 \mathrm{mg}) \mathrm{HF}$ furnace exp, MC $28,1 \mathrm{Hr}$ with Cd $J=63.1$} \\
\hline 1 & 550 & 100.00 & 0.00 & 0.000 & - & - \\
\hline 2 & 600 & 100.00 & 0.23 & 0.093 & - & - \\
\hline 3 & 650 & 100.00 & 0.32 & 0.087 & - & - \\
\hline 4 & 700 & 100.00 & 0.30 & 0.081 & - & - \\
\hline 5 & 750 & 99.70 & 0.38 & 0.082 & 0.335 & $0.150 \pm 0.509$ \\
\hline 6 & 800 & 99.97 & 0.38 & 0.103 & 0.040 & $0.018 \pm 0.406$ \\
\hline 7 & 850 & 99.83 & 0.53 & 0.106 & 0.087 & $0.039 \pm 0.223$ \\
\hline 8 & 900 & 98.90 & 1.15 & 0.072 & 0.393 & $0.176 \pm 0.164$ \\
\hline 9 & 950 & 98.37 & 2.60 & 0.053 & 0.297 & $0.133 \pm 0.084$ \\
\hline 10 & 1,000 & 94.57 & 4.55 & 0.044 & 0.447 & $0.200 \pm 0.039$ \\
\hline 11 & 1,050 & 91.38 & 4.07 & 0.054 & 0.484 & $0.216 \pm 0.026$ \\
\hline 12 & 1,100 & 88.37 & 3.96 & 0.058 & 0.526 & $0.235 \pm 0.020$ \\
\hline 13 & 1,150 & 84.61 & 4.39 & 0.051 & 0.531 & $0.237 \pm 0.015$ \\
\hline 14 & 1,200 & 82.16 & 5.11 & 0.039 & 0.543 & $0.243 \pm 0.013$ \\
\hline 15 & 1,250 & 86.59 & 5.42 & 0.041 & 0.540 & $0.242 \pm 0.018$ \\
\hline 16 & 1,350 & 90.87 & 8.46 & 0.057 & 0.517 & $0.231 \pm 0.025$ \\
\hline
\end{tabular}




\begin{tabular}{|c|c|c|c|c|c|c|}
\hline \multicolumn{7}{|c|}{ HF furnace experiments } \\
\hline Step & $\mathrm{T}^{\circ} \mathrm{C}$ & $\begin{array}{l}\text { Atmospheric } \\
\text { contamination }(\%)\end{array}$ & $39 \operatorname{Ar}(\%)$ & 37ArCa/39ArK & 40Ar*/39ArK & Age $(\mathrm{Ma} \pm 1 \sigma)$ \\
\hline 17 & 1,450 & 85.73 & 58.15 & 0.072 & 0.573 & $0.256 \pm 0.019$ \\
\hline Fuse & 1,550 & 100.00 & 0.02 & 0.472 & - & - \\
\hline \multicolumn{7}{|c|}{ (Integrated age: $0.231 \pm 0.013$ ) } \\
\hline \multicolumn{7}{|c|}{ Plateau age (steps 12-17) used $0.250 \pm 0.013$} \\
\hline \multicolumn{7}{|c|}{ M1449, sample Ubi 71 Biotite $(160 \mathrm{mg}) \mathrm{HF}$ furnace exp MC $28,1 \mathrm{Hr}$ with $\mathrm{Cd}, J=62.9$} \\
\hline 1 & 470 & 100.00 & 0.00 & 0.000 & - & - \\
\hline 2 & 550 & 99.74 & 0.01 & 0.483 & 11.077 & $4.966 \pm 21.028$ \\
\hline 3 & 600 & 100.00 & 0.28 & 0.157 & - & - \\
\hline 4 & 650 & 99.95 & 0.38 & 0.149 & 0.065 & $0.029 \pm 0.453$ \\
\hline 5 & 700 & 99.93 & 0.55 & 0.150 & 0.041 & $0.018 \pm 0.254$ \\
\hline 6 & 750 & 100.00 & 0.61 & 0.175 & - & - \\
\hline 7 & 800 & 98.54 & 0.72 & 0.212 & 0.524 & $0.235 \pm 0.182$ \\
\hline 8 & 850 & 97.03 & 1.67 & 0.139 & 0.501 & $0.225 \pm 0.086$ \\
\hline 9 & 900 & 92.94 & 3.26 & 0.095 & 0.510 & $0.229 \pm 0.033$ \\
\hline 10 & 950 & 93.27 & 3.42 & 0.111 & 0.489 & $0.219 \pm 0.034$ \\
\hline 11 & 1,010 & 89.18 & 6.20 & 0.074 & 0.545 & $0.245 \pm 0.023$ \\
\hline 12 & 1,050 & 81.79 & 11.55 & 0.055 & 0.580 & $0.260 \pm 0.013$ \\
\hline 13 & 1,100 & 81.52 & 10.11 & 0.085 & 0.577 & $0.259 \pm 0.013$ \\
\hline 13 & 1,150 & 77.96 & 25.20 & 0.084 & 0.596 & $0.268 \pm 0.011$ \\
\hline 15 & 1,200 & 64.75 & 28.98 & 0.078 & 0.579 & $0.260 \pm 0.006$ \\
\hline 16 & 1,250 & 54.92 & 5.76 & 0.034 & 0.580 & $0.260 \pm 0.005$ \\
\hline 17 & 1,280 & 61.82 & 0.91 & 0.047 & 0.695 & $0.312 \pm 0.017$ \\
\hline 18 & 1,340 & 77.52 & 0.37 & 0.079 & 0.505 & $0.227 \pm 0.036$ \\
\hline 19 & 1,400 & 100.00 & 0.02 & 0.564 & - & - \\
\hline Fuse & 1,450 & 100.00 & 0.00 & 1.408 & - & - \\
\hline \multicolumn{7}{|c|}{ (Integrated age: $0.245 \pm 0.008$ ) } \\
\hline \multicolumn{7}{|c|}{ Plateau age (steps 11-16) used $0.261 \pm 0.005$} \\
\hline
\end{tabular}



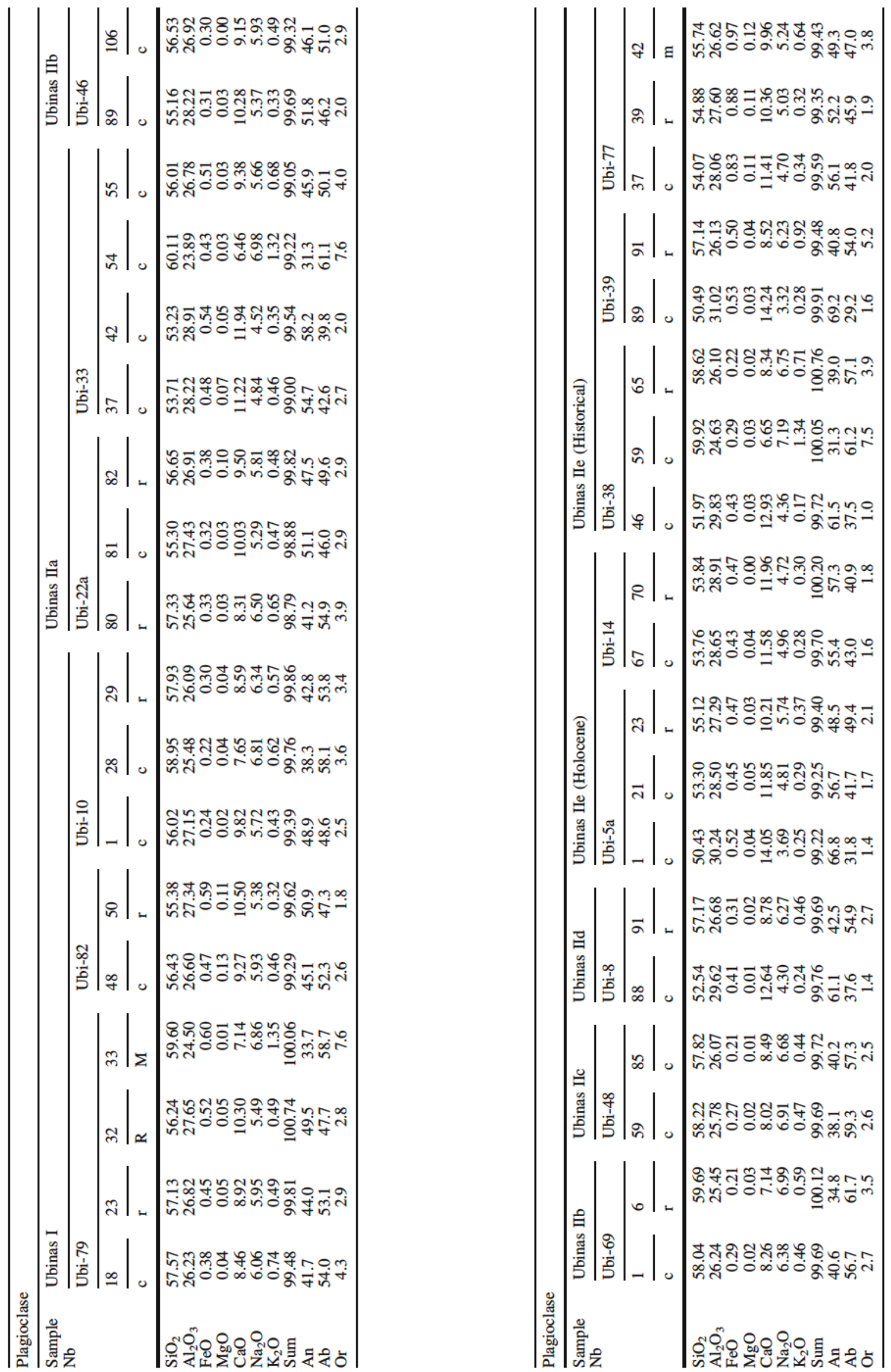

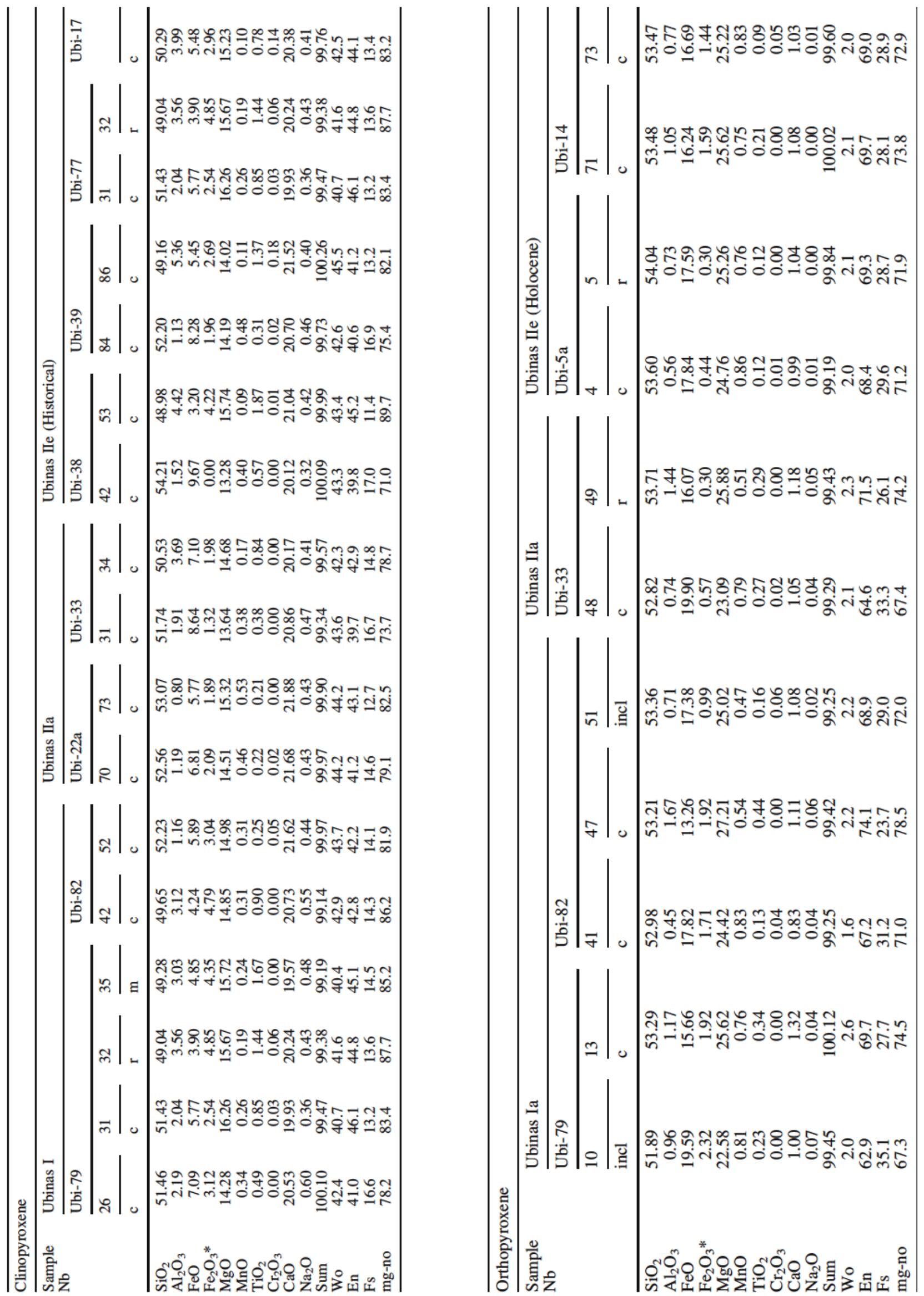

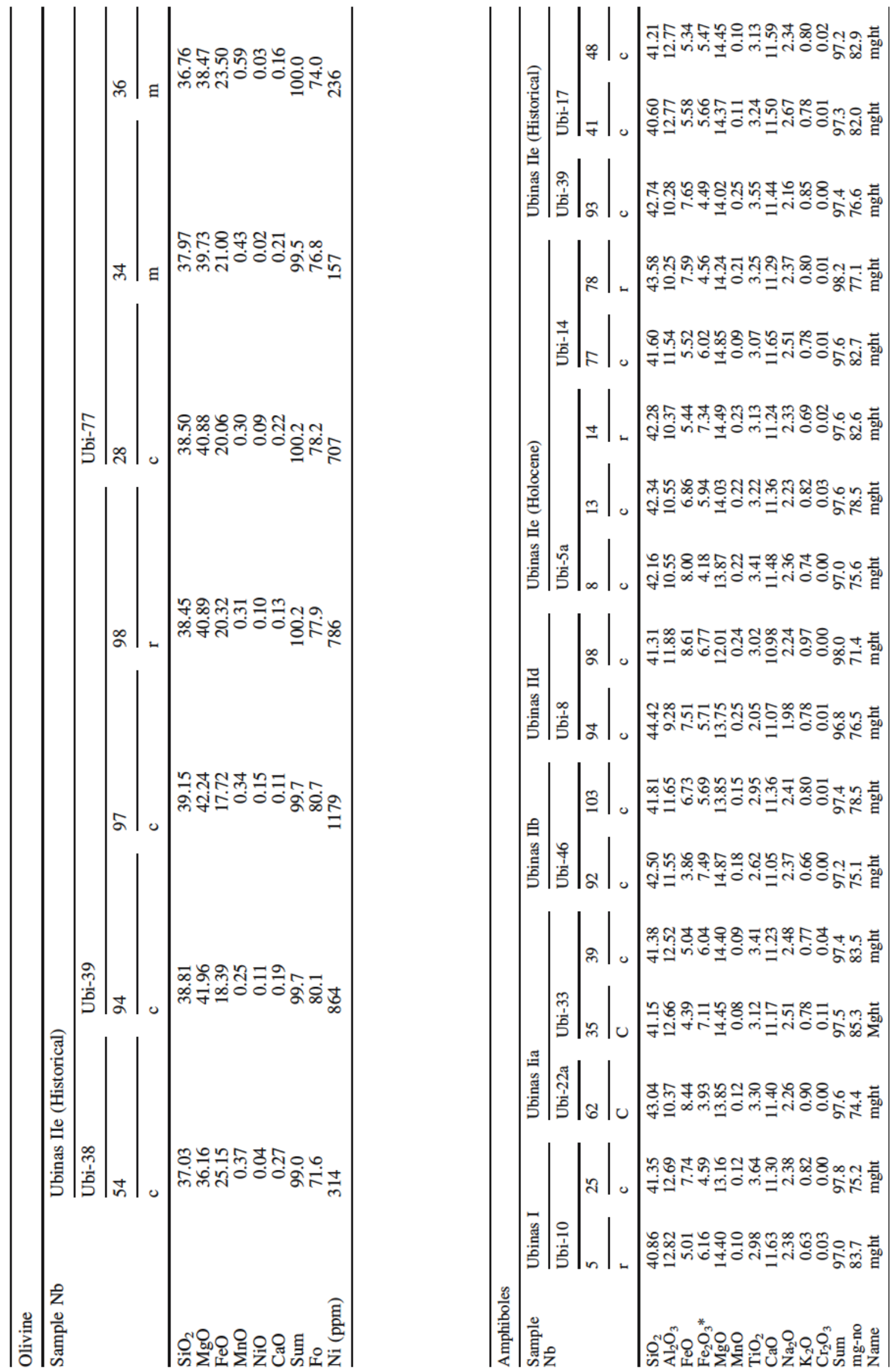


\begin{tabular}{|c|c|c|c|c|c|c|c|c|c|c|c|c|}
\hline \multicolumn{13}{|l|}{ Biotite } \\
\hline \multirow{4}{*}{$\begin{array}{l}\text { Sample } \\
\mathrm{Nb}\end{array}$} & \multicolumn{3}{|c|}{ Ubinas I } & \multicolumn{4}{|c|}{ Ubinas IIb } & \multirow{3}{*}{$\begin{array}{l}\frac{\text { Ubinas IIc }}{\text { Ubi-48 }} \\
84\end{array}$} & \multirow{2}{*}{\multicolumn{2}{|c|}{$\frac{\text { Ubinas IId }}{\text { Ubi-8 }}$}} & \multirow{2}{*}{\multicolumn{2}{|c|}{$\frac{\text { Ubinas IIe }}{\text { Ubi-38 }}$}} \\
\hline & \multicolumn{2}{|c|}{ Ubi-82 } & \multirow{2}{*}{$\frac{\text { Ubi-10 }}{34}$} & \multicolumn{2}{|c|}{ Ubi-46 } & \multicolumn{2}{|c|}{ Ubi-69 } & & & & & \\
\hline & 45 & 59 & & 87 & 91 & 15 & 9 & & 86 & 93 & 30 & 31 \\
\hline & $\mathrm{c}$ & $\mathrm{c}$ & $\mathrm{C}$ & c & $\mathrm{c}$ & $\mathrm{c}$ & $\mathrm{r}$ & $\mathrm{c}$ & c & c & c & $\mathrm{r}$ \\
\hline$\overline{\mathrm{SiO}_{2}}$ & 36.58 & 36.66 & 36.96 & 37.11 & 37.00 & 36.91 & 36.91 & 36.49 & 36.93 & 37.16 & 36.50 & 36.93 \\
\hline $\mathrm{Al}_{2} \mathrm{O}_{3}$ & 13.87 & 13.46 & 14.11 & 13.74 & 13.63 & 13.79 & 13.79 & 13.97 & 14.05 & 14.49 & 13.52 & 13.65 \\
\hline $\mathrm{FeO}$ & 11.87 & 14.19 & 12.95 & 13.89 & 13.75 & 13.46 & 13.45 & 14.69 & 12.74 & 13.08 & 14.19 & 13.93 \\
\hline $\mathrm{MgO}$ & 16.78 & 15.61 & 16.20 & 14.52 & 15.11 & 15.74 & 15.72 & 14.74 & 15.66 & 15.29 & 14.95 & 15.35 \\
\hline $\mathrm{MnO}$ & 0.05 & 0.09 & 0.09 & 0.19 & 0.20 & 0.18 & 0.15 & 0.21 & 0.16 & 0.14 & 0.23 & 0.11 \\
\hline $\mathrm{TiO}_{2}$ & 6.10 & 5.74 & 4.95 & 4.98 & 4.83 & 4.92 & 4.80 & 4.51 & 4.85 & 5.12 & 6.02 & 5.92 \\
\hline $\mathrm{K}_{2} \mathrm{O}$ & 8.58 & 8.66 & 8.92 & 8.95 & 8.82 & 8.47 & 8.70 & 8.75 & 8.80 & 8.78 & 9.24 & 9.04 \\
\hline $\mathrm{Na}_{2} \mathrm{O}$ & 0.81 & 0.76 & 0.66 & 0.94 & 0.87 & 0.89 & 0.77 & 0.69 & 0.87 & 0.81 & 0.67 & 0.78 \\
\hline $\mathrm{CaO}$ & 0.23 & 0.03 & 0.03 & 0.00 & 0.02 & 0.00 & 0.00 & 0.06 & 0.04 & 0.03 & 0.02 & 0.04 \\
\hline $\mathrm{Cr}_{2} \mathrm{O} 3$ & 0.01 & 0.00 & 0.04 & 0.05 & 0.00 & 0.00 & 0.00 & 0.04 & 0.00 & 0.00 & 0.00 & 0.00 \\
\hline Sum & 94.9 & 95.2 & 94.9 & 94.4 & 94.2 & 94.3 & 94.3 & 94.2 & 94.1 & 94.9 & 95.3 & 95.8 \\
\hline
\end{tabular}

\section{References}

Allègre CJ, Provost A, Jaupart C (1981) Oscillatory zoning: a pathological case of crystal growth. Nature 294:223-228

Bullard FM (1962) Volcanoes of southern Peru. Bull Volcanol 24:443-453

Barazangi M, Isacks B (1976) Spatial distribution of earthquakes and subduction of the Nazca plate beneath South America. Geology 4:686-692

Bourdon B, Wörner G, Zindler A (2000) U-series evidence for crustal involvement and magma residence times in the petrogenesis of Parinacota Volcano, Chile. Contrib Mineral Petrol 139(4):458-469

Davidson JP, de Silva S (2000) Composite volcanoes. In: Sigurdsson $\mathrm{H}$ et al (eds) Encyclopedia of volcanoes. Academic Press, San Diego, pp 663-681

Davidson JP, McMillan NJ, Moorbath S, Wörner G, Harmon RS, Lopez Escobar L (1990) The Nevados de Payachata volcanic region $\left(18^{\circ} \mathrm{S} / 69^{\circ} \mathrm{W}, \mathrm{N}\right.$. Chile) II. Evidence for widespread crustal involvement in Andean magmatism. Contrib Mineral Petrol 105:412-432

de Silva SL, Francis PW (1991) Volcanoes of the Central Andes. Springer, Berlin Heidelberg New York, pp 216

de Silva SL, Davidson JP, Croudace IW, Escobar A (1993) Volcanological and petrological evolution of volcan Tata Sabaya, SW Bolivia. J Volcanol Geotherm Res 55:305-335

Feeley TC, Hacker MD (1995) Intracrustal derivation of Na-rich andesitic and dacitic magmas: an example from volcan Ollagüe, Andean central volcanic zone. J Geol 103:213-225

Finizola A, Sortino F, Lénat JF, Macedo O, Gonzales K, Ramos D (1998) SP studies of hydrothermal systems and structure on Misti and Ubinas volcanoes, south Peru. In: Second International Workshop on Magnetic and EM Methods in Seismology and Volcanology, Chania, Greece (Abstract)

Finizola A, Sortino F, Lénat JF, Valenza M (2002) Fluid circulation at Stromboli volcano (Aeolian Islands, Italy) from self-potential and $\mathrm{CO}_{2}$ surveys. J Volcanol Geotherm Res 116(1-2):1-18

Finizola A, Sortino F, Lénat JF, Aubert M, Ripepe M, Valenza M (2003) The summit hydrothermal system of Stromboli: new insights from self-potential, temperature, $\mathrm{CO}_{2}$ and fumarolic fluids measurements with structural and monitoring implications. Bull Volcanol 65:486-504

Gerbe MC, Thouret JC (2004) Role of magma mixing in the petrogenesis of lavas erupted through the 1990-1998 explosive activity of the Nevado Sabancaya in southern Peru. Bull Volcanol 66:541-561

Ginibre C, Kronz A, Wörner G (2002) Minor and trace element zoning patterns in volcanic plagioclase: examples for crystalchemical, compositional and kinetic control and implications for magma chamber processes. Contrib Mineral Petrol 143: 300-315

Green TH (1972) Crystallization of calc-alkaline andesite under controlled high-pressure hydrous conditions. Contrib Mineral Petrol 34:150-166

Hantke G, Parodi I (1966) The active volcanoes of Peru. Catalogue of the active volcanoes of the world including solfatara fields, Part XIX, Colombia, Ecuador and Peru. Internat Assoc, Volcanol, Rom 65-73

James ED (1982) A combined $\mathrm{O}, \mathrm{Sr}, \mathrm{Nd}$, and $\mathrm{Pb}$ isotopic and trace element study of crustal contamination in central Andean lavas, I. Local geochemical variations. Earth Planet Sci Lett 57:47-62

Juvigné E, Thouret JC, Gilot E, Gourgaud A, Legros F, Uribe M, Graf K (1997) Etude téphrostratigraphique et bioclimatique du Tardiglaciaire et de l'Holocène de la Laguna Salinas, Pérou méridional. Géogr phys Quat 51(2):219-231

Lipman PW (1997) Subsidence of ash-flow calderas: relation to caldera size and magma-chamber geometry. Bull Volcanol 59:198-218

Mahlburg-Kay S, Mpodozis C, Coira B (1999) Neogene magmatism, tectonism, and mineral deposits of the central Andes $\left(22^{\circ}\right.$ to $33^{\circ} \mathrm{S}$ latitude). In: Skinner BJ (ed) Geology and ore deposits of the central Andes. Soc Econ Geol Spec Publ 7:27-59

Marocco R, del Pino M (1966) Geología del Cuadrángulo de Ichuña. Comisión carta geológica nacional, Bol 14: pp. 57 and 1 colour map $(1 / 100,000$ scale)

Morimoto N, Fabries J, Fergusson AK, Ginzburg IV, Ross M, Seifert FA, Zussman J, Aoki K, Gottardi G (1988) Nomenclature of pyroxenes. Bull Mineral 111:535-550

Nakamura M, Shimakita S (1998) Dissolution origin and syn-entrapment compositional changes of melt inclusions in plagioclase. Earth Planet Sci Lett 161:119-133

NCEP-NCAR (1998) National Center for Environmental Prediction-National Center for Atmospheric Research, Climate Data Assimilation System, Reanalysis Project, monthly mean data from the period 1979-1995. http://www.gfdl.gov/ jjp/ncap_data.html

Papike JJ, Cameron KL, Baldwin K (1974) Amphiboles and pyroxenes: characterization of other than quadrilateral components and estimates of ferric iron from microprobe data (Abstract). Geol Soc Am Abstracts with Programs 6:1053-1054

Renne PR, Swisher CC, Deino AL, Karner BD, Owens T, DePaolo DJ (1998) Intercalibration of standards, absolute ages and uncertainties in ${ }^{40} \mathrm{Ar}{ }^{39} \mathrm{Ar}$ dating. Chem Geol, Isotope Geosci Sect 145(1-2):117-152

Rivera M, Thouret JC, Gourgaud A (1998) Ubinas, el volcán más activo del sur del Perú desde 1550: Geología y evaluación de las amenazas volcánicas. Bol Soc Geol Perú 88:53-71 
Sébrier M, Soler P (1991) Tectonics and magmatism in the Peruvian Andes from Late Oligocene time to the Present. Geol Soc Am Spec Pap 265:259-277

Seltzer G (1990) Recent glacial history and paleoclimate of the Peruvian-Bolivian Andes. Quat Sci Rev 9:137-152

Simkin T, Siebert L (1994) Volcanoes of the world-a regional directory, gazeteer and chronology of volcanism during the last 10,000 years, 2nd edn. Global Volcanism Program. Smithsonian Institution, Washington, DC pp 348

Singer B, Dungan MA, Layne GD (1995) Textures and Sr, Ba, Mg, $\mathrm{Fe}, \mathrm{K}$, and $\mathrm{Ti}$ compositional profiles in volcanic plagioclase: clues to the dynamics of calc-alkaline magma chambers. Am Mineral 80:776-798

Steiger RH, Jaeger E (1977) IUGS Subcommission on geochronology: convention on the use of decay constants in geoand cosmochronology. Earth Planet Sci Lett 36:359-362

Sun S, McDonough WF (1989) Chemical and isotopic systematics of oceanics basalts: Implications for mantle composition and processes. Magmatism in the ocean basin. Geol Soc Spec Publ $42: 313-345$
Thouret JC, Le Pennec JL, Woodman RS Macedo O (1996) Ubinas (Perú), Increased fumarolic activity prompts seismic and other monitoring. Global Volc Network Bull, Smithsonian Institution, Washington, DC 7

Thouret JC, Finizola A, Fornari M, Suni J, Legeley-Padovani A, Frechen M (2001) Geology of El Misti volcano nearby the city of Arequipa, Peru. Geol Soc Am Bull 113(12):1593-1610

Thouret JC, Juvigné E, Gourgaud A, Boivin P, Dávila J (2002) Reconstruction of the A.D. 1600 eruption at Huaynaputina volcano, Peru, based on the correlation of geologic evidence with early Spanish chronicles. J Volcanol Geotherm Res 115(34):529-570

Tindle AG, Webb PC (1994) Probe-Amph - a spreadsheet program to classify microprobe-derived amphibole analyses. Comp Geosci 20:1201-1228

Valdivia J (1995) Breve reseña histórica del distrito de Ubinas. Bol consejo de Ubinas, Ubinas, Perú, pp 40

Wörner G, Harmon RS, Davidson J, Moorbath S, Turner D, McMillan N, Nye C, Lopez-Escobar L, Moreno H (1988) The Nevados de Payachata volcanic region $\left(18^{\circ} \mathrm{S} / 69^{\circ} \mathrm{W}, \mathrm{N}\right.$. Chile $)$ I. Geological, geochemical and isotopic observations. Bull Volcanol 50:287-303 